\title{
International Evidence on the Determinants of Organisational Ethical Vulnerability
}

\author{
Dr Subhan Ullah \\ Lecturer in Accounting \\ Hull University Business School \\ University of Hull \\ Cottingham Road \\ Hull \\ HU6 7RX \\ United Kingdom \\ email: subhan.ullah@hull.ac.uk \\ Dr Sardar Ahmad \\ Lecturer in Accounting \\ University of Liverpool Management School \\ Chatham Street \\ Liverpool \\ L69 7ZH \\ United Kingdom \\ email: sardar.ahmad@liverpool.ac.uk
}

\author{
Professor Saeed Akbar* \\ Professor and Head of Accounting and Finance \\ Hull University Business School \\ University of Hull \\ Cottingham Road, \\ Hull \\ HU6 7RX \\ United Kingdom \\ Email: s.akbar@hull.ac.uk \\ Dr Devendra Kodwani \\ Senior Lecture in Finance \\ The Open University Business School \\ Walton Hall
Milton Keynes
MK7 6AA \\ United Kingdom \\ email: devendra.kodwani@open.ac.uk
}

* Corresponding author 


\title{
International Evidence on the Determinants of Organisational Ethical Vulnerability
}

\begin{abstract}
This paper proposes a model to explain what makes organisations ethically vulnerable. Drawing upon legitimacy, institutional, agency and individual moral reasoning theories we consider three sets of explanatory factors and examine their association with organisational ethical vulnerability. The three sets comprise external institutional context, internal corporate governance mechanisms and organisational ethical infrastructure. We combine these three sets of factors and develop an analytical framework for classifying ethical issues and propose a new model of organisational ethical vulnerability. We test our model on a sample of 253 firms that were involved in ethical misconduct and compare them with a matched sample of the same number of firms from 28 different countries. The results suggest that weak regulatory environment and internal corporate governance combined with profitability warnings or losses in the preceding year increase organisational ethical vulnerability. We find counterintuitive evidence suggesting that firms' involvement in bribery and corruption prevention training programmes is positively associated with the likelihood of ethical vulnerability. By synthesising insights about individual and corporate behaviour from multiple theories, this study extends existing analytical literature on business ethics. Our findings have implications for firms' external regulatory settings, corporate governance mechanisms and organisational ethical infrastructure.
\end{abstract}

Keywords: Organisational ethical vulnerability, corporate governance, business ethics, media, compliance, corporate ethics training programmes 


\section{Introduction}

The purpose of this paper is to search for explanations for ethically questionable practices that manifest in corporate scandals of various kinds. We look for possible internal and external factors to an organisation that may explain corporate vulnerability to ethically questionable practices. As a legal entity organisation does not have any inherent moral compass to evaluate the consequences of its actions from an ethical perspective ${ }^{1}$. Organisations do not act but people within organisations do; hence, while explaining unethical corporate behaviour, the individual and collective behaviour of people needs to be acknowledged as a potential factor. We argue that ethical choices within organisations are influenced by individual values, internal control systems and external institutions. This argument is not new and earlier studies provide a descriptive framework for classifying ethical issues in business and managerial behaviour (e.g. Carroll, 1978; Nash, 1990). Jackson et al.'s (2013) conceptual framework is the closest that identifies three factors (individual, organisational and contextual) to explain ethical choices in organisations. This conceptual framework recognises that the unit of analysis in ethical decision- making is both individual and organisation, but calls for empirical research.

We therefore argue that, although recognising such contractual obligations normatively is useful, using this insight for understanding actual corporate conduct is not adequate without an analytical framework. This study therefore adds to the existing descriptive frameworks of classifying ethical issues by proposing a new construct of 'Organisational Ethical Vulnerability' (OEV) as an analytical framework. We use this framework to seek evidence of three interacting agencies of individual, organisation and the system within which organisations operate and their impact on the corporate behaviour manifested in corporate scandals. We use the word 'scandal' in its commonly understood meaning found in the Oxford English Dictionary, i.e. "an action or event regarded as morally or legally wrong and causing general public outrage" 2 . Corporate scandal is an event or action that is seen as morally or legally wrong and generates negative public reaction, creating controversies.

Corporate scandals are manifestations of unethical behaviour as they mainly mean and imply damage to one or more of an organisation's stakeholders. For example, harm done by manipulation of earnings and reporting not only leads to a loss to investors but also damages the investors' trust in financial markets, which increases the overall cost of financing in an economy with adverse consequences on investment. A US government commissioned report into the causes of the financial crisis in 2007-08 concluded that "there was a systematic breakdown in accountability and ethics" (GPO-FCIC, 2011, p. xxii). The report identified not only individual irresponsibility, but also listed the financial industry's general 
acceptance of the erosion of standards. The commission, however, draws attention to the wider business environment landscape that let unethical practices in the industry continue to a point where the catastrophic crisis became inevitable. The report documents that causes should be viewed in the context of "human nature and individual and societal responsibility" (GPO-FCIC, 2011, p. xxii). We sympathise with this view, which motivates us to look for a framework to analyse this complex phenomenon. Our search leads us to consider the role of individuals as managers in organisations.

We therefore take agency theory as a starting point in this research. This theory offers a framework to model the behaviour of managers as individuals in relation to principals, primarily shareholders in Anglo-American corporations, who entrust the managers to manage corporations in the principals' best interests. Commonly attributed reasons for the agency problem are incomplete contracts and information asymmetry. The conflict of interest between managers and principals presents an ethical dilemma, because managers favour their own interest instead of that of the principals and are therefore committing a breach of trust. This is mainly due to the information advantage that managers possess over the principals, and, despite the terms and conditions of their contracts, they are able to put their own interests first. If managers in large organisations have incomplete contracts and have information advantage, this may not cause an agency problem; it is the managers' choice to use these two factors as instruments that exacerbates the agency problem.

At a more fundamental level, we restate the agency problem as an ethical problem rather than a contractarian anomaly. An objection to this proposition may be that trust is not legally construed as a binding condition in a contract; hence, breach of trust is not within the scope of agency theory. The response to such an objection is not far from the normal expectations of the fiduciary relationship that managers are supposed to have with their principals. The fiduciary duties of managers and boards of directors require that the agency relationship is based on trust and confidence. Therefore, we restate the agency problem as ethical tension for managers and corporate governance mechanisms as a way of mitigating the agency problem. An important aspect of this restatement is that it allows us to consider internal corporate governance systems as an attempt to deal with ethical problems where the agency relation is an instrument through which ethical choice is exercised.

Institutional theory offers a lens to explore the interaction of organisational responses in relation to societal expectations (Chen and Roberts, 2010). This theory focuses on the social and other structures and norms external to an organisation to which it may conform. The externally focused corporate governance mechanisms such as transparent reporting, and compliance with codes and regulations constitute a response to the external organisational and institutional environment. Thus, we combine individual, organisational and institutional contexts as three agencies that 
increase or decrease corporations' vulnerability of ethical conduct. In section two, we develop the concept of ethical vulnerability as a function of these three interrelated factors.

We tested our model by developing several hypotheses and found that most factors related to internal corporate governance and financial performance, external institutional and business context, and organisational ethical infrastructure, are good predictors of OEV. The results show that weak regulatory environment and internal corporate governance combined with profitability warnings or losses in the preceding year increase OEV. We find counterintuitive evidence suggesting that training employees on the prevention of corruption and bribery increases OEV. Our analytical framework enables us to take a holistic view and analyse a range of external and internal factors affecting organisational ethical choices.

The rest of this paper is organised as follows. Section 2 develops a framework of OEV by discussing the role of individual, internal and institutional contexts. In section 3, we discuss ethics in light of individuals' moral judgement and institutional theories to develop our hypotheses. This is followed by section 4, which describes the methodology, sample and data collection procedures. Section 5 provides a discussion on the main analysis and results, whilst section 6 concludes this paper by summarising the findings and contributions.

\section{The Organisational Ethical Vulnerability (OEV) Framework}

Fraudulent, unethical and illegal corporate behaviour assumes significance beyond the breach of agency contract with shareholders, who obviously suffer a loss in terms of the market value of their investment. Accounting practices involving earnings management are widespread in all sectors, and undermine the reliability of financial statements and the confidence of investors in financial markets (Global Fraud Study, 2016). Some recent corporate scandals involving major companies around the world (e.g. Volkswagen and Mitsubishi's fuel emission, and Tesco's accounting scandals) illustrate the range of corporate behaviour that undermines expected commitment towards transparent and responsible business behaviour. These scandals were considered by the market to be shocks and had a devastating effect on the market value of the involved companies. The level of market reaction to these scandals indicates that shareholders give a great deal of importance to business ethics and expect businesses to be ethical. However, attempts to theoretically model such corporate behaviour have been fragmented, focusing on individuals, or on internal organisational controls or on external factors such as law enforcement. We propose to synthesise different theoretical perspectives to develop an analytical framework to determine what makes organisations ethically vulnerable. 
We start with a discussion of the concept of ethics and its relation to business context. Managers' individual and ethical decision making are then discussed, followed by a discussion of earlier attempts that offered approaches to classify ethical issues in relation to the individual, organisation and external environment. We add to this strand of literature by proposing an analytical framework outlining the expected relationship between the three interacting agencies. In this research ethical vulnerability is used in the sense of susceptibility of an organisation to unethical behaviour. Such corporate behaviour includes illegal as well as legal but ethically questionable activities. We distinguish this from a notion of vulnerability found in the literature where one party is seen as vulnerable to another party due to power or information advantage (Brown, 2013). Vulnerability of investors to managerial behaviour when directors in a corporate business entity fail in their fiduciary duties to protect the interests of shareholders is an example of vulnerability. This example is articulated in finance literature as the agency problem, which is also the rationale underpinning corporate governance codes. We argued above that the agency problem can be seen as an ethical issue as it is a breach of trust in the principal agent relationship in which information asymmetry and/or incomplete contract may be used by an agent as instruments. However, such a relationship-based vulnerability is a distinct concept. Organisational ethical vulnerability, we propose, is a phenomenon of organisations becoming prone to unethical business conduct as manifested through business decisions that violate ethical principles.

Nash (1990, p.5) defines business ethics as "the study of how personal moral norms apply to the activities and goals of commercial enterprise. It is not a separate moral standard, but the study of how the business context poses its own unique problems for a moral person who acts as an agent of this system." Three areas of managerial decision making identified by Nash are choices about what the laws should be and whether to follow them; choices about economic and social issues outside the domain of law; and choices about the priority of self-interest over the company's interests. This scope of ethical decision making thus encompasses all actions and 'all systems involved in the exchange of goods and services'. Schwartz (2016) proposes an integrated approach to ethical decision making which is modelled as a function of individual moral capacity and situational factors, such as, ethical issues on hand, organisational setup (we discuss this below) and personal context, for instance, individuals' personal circumstances, motives, time and financial constraints.

The role of an individual is central to understanding corporate behaviour. Carroll (1978) offers a five-level framework to improve ethical behaviour in society, namely: individual, organisational, association, societal and international. However, while Carroll's framework is plausible it is not a theoretically grounded proposition. To address this issue, we provide theoretical grounding about moral 
judgement by individuals in section three. Likewise, Matthews et al. (1985) developed a framework for classifying ethical issues and levels using three categories of ethics: ethics of the person, ethics of the organisation and ethics of the system. In this classification, the institutional context comprising the customs, laws and values of a region is covered in ethics of the system. Ethics of the organisation covers written formal, informal norms and ways of doing business, and the ethics of a person category comprises personal values and principles. Nonetheless, this normative framework does not lend itself to empirical testing, primarily because, in the absence of a clear definition of the three components that could be observed and in the absence of a clear statement of how the three components interact, the analytical value of this framework is constrained. Other studies have focused on individual choices in simulated scenarios with student participants (e.g. Lopez et al., 2009; McDevitt et al., 2007). Along with Jackson et al. (2013), all these studies call for empirical research that use an integrated model that could explain ethical decision making in organisations.

From the foregoing discussion, we find that ethics at the individual level are moral principles including values that guide an individual's approach to dealing with ethical dilemmas. We also note that, in the case of managers, the organisational context - such as codes of conduct - has an impact on the ethical choices and, finally, there are external customs, norms and codes. We therefore see this as part of a wider set of possible factors that may lead to unethical corporate behaviour. Schwartz (2016) calls individual accountability, ethical conduct, and internal checks and balances within the organisational environment the situational context constituting an 'ethical infrastructure'. Matthews et al. (1985) call this the ethics of the person and ethics of the organisation in their model. The internal organisational factors that influence the ethical conduct of a business entity include organisational policies such as remuneration policy, whistle blowing, corporate training, rewards and punishments for performance targets, codes of conduct, codes of ethics and organisational culture (Coffee Jr, 2005). In summary, this set includes organisational efforts that enhance the moral capacity of individuals and comprises business ethics initiatives and executive skills that affect organisational ethical vulnerability. We adapt the 'ethical infrastructure' term from the theoretical model of an organisation's ethical effectiveness from Tenbrunsel et al. (2003) and use it as the Organisational Ethical Infrastructure (OEI) construct in our proposed framework. If a person's behaviour is reinforced by organisational commitment and action to support ethical choices, this may be expected to reduce OEV.

Internal corporate governance systems - such as, the role of non-executive directors and the independence of audit committees - are expected to critically scrutinise management decisions and thereby provide a check on unethical practices. Executive compensation is viewed as an incentive to manage financial performance and could be a potential incentive to indulge in unethical practices such as 
management of earnings and fraudulent financial reporting practices. Effective internal corporate governance is therefore expected to reduce organisational ethical vulnerability. We call this set the Internal Corporate Governance and Financial Performance (ICGFP). It comprises internal corporate governance mechanisms and financial performance context, which is informed by the agency theory propositions (Jensen and Meckling, 1976). These factors have been examined in various studies as internal corporate governance mechanisms (e.g. Cai et al., 2012; Ntim and Soobaroyen, 2013).

Drawing from institutional theories and the above discussion (also see Schwartz, 2016; Nash, 1990; and Carroll, 1978), it is clear that the external institutional and business context comprising country-specific quality of regulation, investor protection, rule of law, governance and economic development affects OEV. We call this External Context and Impact Enablers (ExCItE). The foregoing articulation of the potential factors that impact OEV provides analytical schema (Figure 1) that we use to test a framework of OEV. We posit that OEV is a function of ExCItE, OEI and ICGFP. In this model, we took incidence of corporate scandals as a proxy for organisational ethical vulnerability.

Figure 1: Model of organisational ethical vulnerability
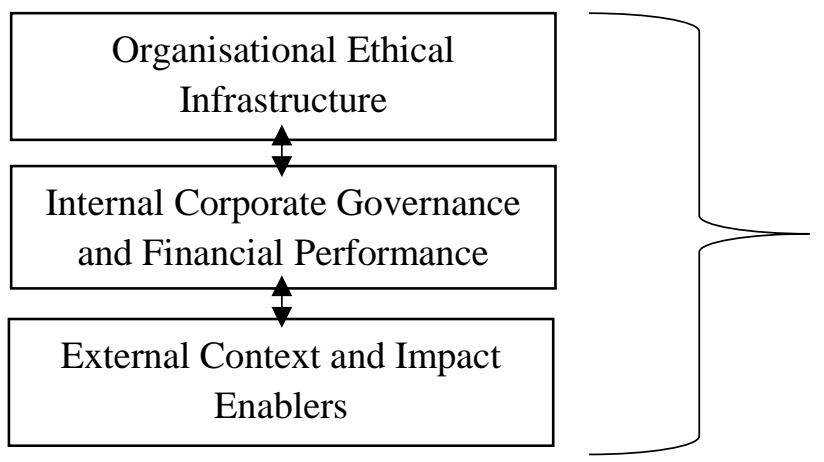

\begin{tabular}{c}
\hline Organisational Ethical \\
Vulnerability
\end{tabular}

\section{Hypotheses development}

Individual approaches to deal with ethical dilemma have been broadly divided into two main categories. On the one hand, rationalist approaches assume that individuals go through a systematic process of understanding and analysing ethical dilemmas, considering the implications of possible responses to such dilemmas and then arrive at a moral judgement (Kohlberg, 1973; Schwartz, 2016). On the other hand, the intuitionist approach is based on intuition/emotions. The rational process guiding individual choices involves factors such as knowledge, values, attitudes and intentions as well as organisational reference groups, codes and their enforcement, rewards and punishment (Ferrell and Gresham, 1985). Using Kohlberg (1973) model to propose a situational interaction process of moral reasoning, Trevino (1986) argues that the rationalist process of moral judgement involves interaction 
between the person's stage of moral development and the situation, and proposed a 'person-situation interactionist' model of ethical decision-making. This implies that ethical decision making is a function of an individual cognitive process that involves moral development/capacity/orientation, and its interaction with situational factors. Jones (1991) introduced another component by identifying the nature of the ethical issue itself as a factor, and argues that the ethical intensity of an issue varies in terms of consequences and the nature of those consequences which affects decision making.

The foregoing discussion of the individual ethical decision-making process shows that it involves interaction with other organisational actors, processes and policies as well as the external context of the business, which all have a bearing on decision making. This leads us to consider theories that situate organisations in a wider societal context and theorise about organisational conduct by exploring the relationship between organisation and society. There are different theoretical perspectives that help in understanding the organisation-society relationship. Chen and Roberts (2010) discuss four overlapping theories (legitimacy theory, institutional theory, resource dependence theory and stakeholder theory) in the context of social and environmental accounting research. ${ }^{3}$ Of particular relevance to our study are legitimacy and institutional theories as we seek to establish the likely impact of various factors that may prevent unethical practices.

Organisational legitimacy depends on the perception of wider stakeholders in society regarding the congruence of organisational and social goals. It is worth noting that an organisation's legitimacy is conferred by external stakeholders. Therefore, organisational response may be guided by the impact of business decisions on external stakeholders' perception about the company. Institutional theory argues that, in order to seek legitimation, organisations respond to social, legal and traditional institutional structures (Chen and Roberts, 2010). This theory, however, differs from legitimacy theory in its scope. While legitimacy of a business activity may be questioned by value systems, institutional theory considers the established norms, laws and customs that an organisation is expected to follow to gain legitimacy.

We derive a conceptual framework (see Figure 1) for analysing organisational ethical vulnerability. This framework is based on the propositions of agency, legitimacy and institutional theories, and combines insights from models of individual ethical decision making and corporate behaviour. The three constructs we propose draw from an integrated model of individual decision making (Schwartz, 2016). We argue that considering only individual ethical vulnerability is unlikely to offer a good explanation about organisational controversies as there are important situational factors within and outside an organisation that are part of an individual's ethical decision-making process. This leads us to propose three 
overlapping sets of potential factors that may explain OEV. In the following section, we organise and discuss relevant literature under these three constructs and develop hypotheses accordingly.

\section{External context and impact enablers (ExCItE)}

Institutional theory proposes that organisational choices are constrained and guided by the social, legal and economic contexts of the countries in which they operate. Similarly, under the propositions of legitimacy theory, organisational activities are judged on the basis of the value systems of the societies in which they operate. This leads us to propose that organisations are expected to conduct their business using ethical principles, and comply with the legal and regulatory requirements of the countries in which they operate. Hence, by using country-level factors we expect to have an enabling impact on ethical business practices. Country-level institutional quality and efficient regulatory systems offer significant protections for investors and stakeholders.

The law and finance literature suggests that, as compared to civil law systems, common law countries have the strongest protection for investors (La Porta et al., 1998). Existing literature in this area documents that country-level governance factors (e.g. rule of law, regulation quality and government effectiveness) and economic indicators (e.g. GDP and per capita income) significantly affect firmlevel governance practices (Ntim and Soobaroyen, 2013). Where country-level institutions are weak and firm-level enforcement mechanisms are not strong enough, the internal and external control mechanisms would not safeguard the interests of shareholders and stakeholders. In a society, where ethical standards are high, the ethical expectation of a business will also be high, and, in seeking legitimacy, organisations will have to conform to strict ethical standards. In line with this, existing evidence suggests that strong external governance mechanisms (e.g. legal systems) are complementary mechanisms which define the formal and informal guidelines for the board of directors, ownership structure and executive compensation (Aguilera et al., 2015). In order to capture the impact of country-level regulation, we include regulation quality, strength of investor protection, rule of law and government effectiveness as the country-level factors in this study, and apply an integrated framework of country-level governance indicators and firm-level governance mechanisms to develop the following hypothesis:

$\mathrm{H}_{1}$ : Country-level institutional quality is negatively associated with organisational ethical vulnerability. 


\section{Organisational ethical infrastructure (OEI)}

Organisational ethical infrastructure also affects the ethical decision making of individuals, which in turn affects the ethical behaviour of organisations (Craft, 2013). A corporate ethics programme and initiative covers "the values, policies and activities' that affect firms' behaviour" (Brenner, 1992, p. 393). It is therefore argued that developing a code of ethics and business conduct will not only help in promoting ethical behaviour but can also be used as a publicity tool to preserve or legitimise corporate actions (Rodriguez-Dominguez et al., 2009). Moreover, in the age of technology and excessive availability of information, firms are increasingly facing pressures from stakeholders and regulators to develop their own code of ethics. The print, electronic and social media are amongst the other sources of external disciplinary mechanisms which have recently been proven very effective in naming and shaming unethical corporate behaviour (Wang and Ye, 2015). As a result, firms are sensitive about their corporate reputation and public image. In the event of an actual or potential unethical activity, a vibrant media may drag in the top corporate officials from 'boardroom to courtroom' and eventually to the newsroom (Brickey, 2008).

In addition, existing literature generally divides a firm's commitment to business ethics into two dimensions, namely: (a) the implicit dimensions and (b) the explicit dimensions, where the implicit dimensions include ethical leadership, corporate culture and ethical training, and the explicit dimensions include the existence of policy manuals, code of ethics, ethics committees and ethics hotlines (Brenner, 1992; Pae and Choi, 2011). In line with this, Rodriguez-Dominguez et al. (2009) argue that local cultures and institutional factors significantly affect the contents of ethics codes in different countries. In recent years, many countries have introduced an organisational code of ethics and other business conduct-related regulations. As a result, large organisations have introduced training programmes that cover different aspects of the prevailing ethics regulations. However, the outcome of existing empirical research on the effectiveness of ethics codes and business conduct is inconclusive (Kaptein and Schwartz, 2008). Discussing the implications of ethics codes, Clegg et al. (2007, p.112) assert that codes provide prescriptive guidance on differentiating between 'good' and 'wrong' things, where an individual has the responsibility for deciding on one of a number of available choices.

There is consensus among academics and practitioners that, multinational organisations are more vulnerable to issues of business ethics since their operations are subject to different regulatory requirements, business practices, social norms, values, and cultures. In response to the emergence of anti-corruption/bribery regulations following recent business scandals, companies have started providing face-to-face and/or online training programmes on the implications of these regulations. Clegg et al. (2007) argue that it needs to be empirically investigated 
how individuals comply/non-comply or ignore and interpret differently certain aspects of ethical codes, because full compliance with ethics codes may not necessarily prevent unethical activities. In line with this, some organisations have taken a more principles-based approach by voluntarily adopting measures to improve business ethics in their operations (such as developing policies on whistleblower protection, providing ombudsman services, establishing hotlines for reporting questionable activities, etc.). Therefore, consistent with the findings of Pae and Choi (2011), we argue that training initiatives and explicit commitment to business ethics will promote ethical behaviour in organisations, and hypothesise that:

$\mathrm{H}_{2}$ : There is a negative relationship between organisational ethical infrastructure and organisational ethical vulnerability.

\section{Internal corporate governance and financial performance (ICGFP)}

\section{Non-executive directors and independence of audit committees}

According to agency theory, the appointment of non-executive directors enhances board-level monitoring and oversight in companies (Jensen, 1993). The presence of non-executive directors (NEDs) on corporate boards has been linked with a number of key functions in the existing literature. First, NEDs help in monitoring management actions on behalf of shareholders; second, they provide strategic advice on key business decisions; and, third, they bring resources to their companies (Fama, 1980). In line with this, Chhaochharia and Grinstein (2007) argue that NEDs bring independent judgement to the board. Consequently, many studies have investigated the impact of NEDs on various organisational outcomes such as financial performance (e.g. Singh et al., 2017), risk disclosure (Ntim and Soobaroyen, 2013) and the survival of firms during difficult economic times (Mangena et al., 2012).

There is also evidence in the existing literature which suggests that increasing the percentage of NEDs on corporate boards and audit committees decrease a firm's probability of restating its financial statements (Agrawal and Chadha, 2005) and the likelihood of corporate fraud (Uzun et al., 2004). Similarly, Chen et al. (2006) document that a higher ratio of NEDs is associated with lower incidence of fraud in Chinese organisations. Likewise, in a cross-country analysis of 760 firms, GarcíaSánchez et al. (2015) find that the presence of independent directors on corporate boards successfully promotes the implementation of ethical codes of conduct in organisations.

The importance of independent NEDs could also be explained by the fact that the majority of corporate governance codes around the world now require companies 
to appoint a specific number of non-executive directors to their boards. In light of the above discussions and based on the assumptions of agency theory, we argue that firms with a higher percentage of NEDs on their corporate boards and audit committees are less likely to be ethically vulnerable. In line with this, the following research hypotheses are proposed:

$H_{3}$ : There is a negative relationship between board independence and organisational ethical vulnerability.

$H_{4}$ : There is a negative relationship between audit committee independence and organisational ethical vulnerability.

\section{Board Size}

Board size is an important factor that has been associated with various organisational outcomes. When a corporate board becomes larger, coordination among members becomes difficult, and thus it becomes dysfunctional and less effective (Jensen, 1993). In contrast, members of smaller boards are more likely to work as a team, which leads to better decision making (Lipton and Lorsch, 1992). While employing the agency theory framework, most of the published studies in this area show a negative relationship between board size and various measures of firm performance (Adams and Jiang, 2017; Yermack, 1996). Other studies that follow the same theoretical framework have examined board size and its association with other organisational outcomes, such as the probability of restatement of companies' financial statements (Agrawal and Chadha, 2005) and the incidence of corporate fraud (Chen et al., 2006). The findings of most of these studies regard board size as an important element in organisational outcomes.

In relation to ethical responsibilities, García-Sánchez et al. (2015) argue that a board size of more than 15 members may lead to a less optimal monitoring process, which may affect a firm's commitment to business ethics. It is therefore argued that, if larger boards are not playing an active role in maintaining business ethics, and are also less effective in the monitoring and decision-making processes, then companies with larger boards are more likely to be involved in corporate scandals. Hence, we hypothesise that:

$H_{5}:$ There is a positive relationship between board size and organisational ethical vulnerability.

\section{Gender Diversity}

Gender diversity on corporate boards is another important governance mechanism which has received considerable attention in recent years. Several countries in Europe (e.g. France, Germany and Norway) have already implemented a fixed quota for female directors on corporate boards. Support for gender diversity on 
boards is also strengthened by the findings of existing corporate governance literature. In particular, evidence in the existing literature has shown a positive relationship between gender diversity and various organisational outcomes, such as firm performance (Post and Byron, 2015), firm reputation (Musteen et al., 2010), success in mergers and acquisitions (Ben-Amar et al., 2013), CEO turnover (Elsaid and Ursel, 2017) and CSR performance (Boulouta, 2013; Harrigan, 1981).

It has also been documented in the existing literature that male and female directors' ethical perception is significantly different (Ibrahim et al., 2009), and, as compared to men, female directors have higher sensitivity towards ethical issues in business operations (Simga-Mugan et al., 2005). For instance, women tend to see questionable business practices as more unethical than men do and try to avoid such practices (Deshpande et al., 2000). We therefore argue that companies with gender diversity on their boards will be less vulnerable to ethics-related incidents, and propose the following hypothesis:

$H_{6}$ : There is a negative relationship between board gender diversity and organisational ethical vulnerability.

\section{Executive compensation}

In order to control the opportunistic behaviour of directors and align their interests with those of the shareholders, firms can use performance-based compensation schemes (Jensen and Meckling, 1976). However, performance-based compensation schemes can lead to short-termism, which is regarded as the downside of such schemes and can create further agency problems (Bebchuk and Fried, 2003). Van Yperen et al. (2011) argue that increasing the emphasis on goal achievement encourages unethical behaviour among individuals, and it is therefore expected that performance-based compensation would encourage boards of directors to become involved in unethical practices. In line with this, Bergstresser and Philippon (2006) show that companies where the CEO's overall compensation is sensitive to company share prices are involved in a higher level of earnings management practices. Similarly, other studies show a positive association between stock-optionbased compensation and the likelihood of fraud (Denis et al., 2006). Furthermore, recent evidence in the existing literature shows that firms select weak performing peers to set CEO performance-based pay (Skovoroda and Bruce, 2017), which could indicate unethical business practice. It is therefore argued that senior executive compensation might encourage directors to try and achieve the target performance measure(s) irrespective of the ethical consequences of their decisions, which could lead to business ethics-related scandals. As a consequence, we propose the following hypothesis:

\section{H7: There is a positive relationship between senior executives' compensation and organisational ethical vulnerability.}




\section{Number of board meetings}

Another widely used corporate governance mechanism in the existing governance research is board activity, which is generally measured as the number of board meetings during an organisation's reporting period. From an agency theory perspective, increasing the number of board meetings may signal increased vigilance and monitoring at the top. However, while investigating the relationship between board activities and firm performance, Vafeas (1999) documents that board activities are likely to increase following poor financial performance in the preceding year. Similarly, Brick and Chidambaran (2010) argue that external market pressures originating from a firm's financial distress may significantly influence the firm's management to change its governance arrangements (e.g. increasing board meetings). In the context of corporate scandals, one argument is that increasing board meetings would enhance a firm's monitoring and thus minimise the likelihood of corporate scandals. A counter argument, however, suggests that, following the publication of a firm's corporate scandal in the media, the number of its board meetings may increase. In line with this, Chen et al. (2006) show a positive relationship between the number of board meetings and the likelihood of accounting scandals for Chinese listed companies. We therefore argue that an increase in the number of board meetings would indicate organisational ethical vulnerability, and propose the following hypothesis:

\section{$H_{8}$ : There is a positive relationship between number of board meetings and} organisational ethical vulnerability.

\section{Single largest shareholder (Blockholder)}

Ownership structure varies across organisations and plays a significant role in their corporate governance mechanisms. Existing studies on ownership structure are generally based on the theoretical proposition of Shleifer and Vishny (1986), who argue that a concentrated ownership system is a superior control mechanism as compared to a dispersed ownership system. However, Chen et al. (2006) argue that in a concentrated ownership structure blockholders may have the incentive to either deter fraud or to engage in unethical activities and expropriate the rights of minority shareholders. Similarly, Shleifer and Vishny (1997, p. 758) report that large investors could use their shareholding rights and redistribute wealth in both efficient and inefficient ways for their self-interest. While investigating the ownership characteristics of the largest corporate scandals in the USA and Europe, Coffee Jr (2005) documents that, as compared to concentrated ownership systems, dispersed ownership systems are more vulnerable to different forms of fraud and earnings management practices.

Accordingly, we argue that corporate scandals arise as a result of poor monitoring and governance, and the ownership structure of firms plays a significant role in 
organisational frauds. We therefore predict that firms that had no scandals are more likely to be owned by large blockholders. Consistent with prior international comparative literature on ownership structure (Thomsen et al., 2006), we use a threshold of five percent or more to include a proxy for the single largest blockholder, and propose that:

\section{$H_{9}$ : There is a negative relationship between blockholders' ownership and organisational ethical vulnerability.}

\section{Financial factors}

The financial health of a firm plays a vital role in its underlying business and ethical behaviour. Several studies have examined the financial characteristics of firms which received adverse rulings from the Financial Reporting Review Panel in the UK (Peasnell et al., 2001); restated their accounting earnings (Agrawal and Chadha, 2005); have been engaged in accounting frauds (Chen et al., 2006); or have been prosecuted for committing financial frauds (Misangyi and Acharya, 2014). The findings of these and other published studies in this area suggest that managers are likely to engage in earning restatement or financial fraud following a firm's poor financial performance (measured by low growth, losses, poor stock performance, etc.). Other studies, such as Barraquier (2011), also confirm that profit-orientation, external market pressures and 'financial capacities' in a competitive environment may restrain managerial ethical behaviour. It is therefore argued that poor financial performance may lead to short-termism and subsequently motivates managers to engage in unethical activities. We include three proxies for poor financial performance, namely: profit warnings in the preceding year, profit warnings during the defect year (year in which the company had a scandal), and losses in the defect year, and hypothesise that:

$H_{10}$ : There is a positive relationship between poor financial performance and organisational ethical vulnerability.

Table 1 presents a summary of all our hypotheses and relates them to their theoretical aspiration and expected results.

Table 1 Summary of hypotheses

\begin{tabular}{llll}
\hline OEV factors & Theoretical inspiration & Hypotheses & $\begin{array}{l}\text { Expected effect } \\
\text { on OEV }\end{array}$ \\
\hline ExCItE & $\begin{array}{l}\text { Institutional theories: Firms will } \\
\text { follow the norms and respond to } \\
\text { external institutions } \\
\text { Moral development, ethical } \\
\text { decision making }\end{array}$ & $\mathrm{H}_{1}$ & Decrease (-) \\
OEI & Agency theory & $\mathrm{H}_{2}$ & Decrease (-) \\
ICGFP & $\mathrm{H}_{3}, \mathrm{H}_{4}, \mathrm{H}_{6}, \mathrm{H}_{9}$ & Decrease (-) \\
& $\mathrm{H}_{5}, \mathrm{H}_{7}, \mathrm{H}_{8}, \mathrm{H}_{10}$ & Increase (+) \\
\hline
\end{tabular}




\section{Data, sample and methodology}

This study investigates whether ExCItE, OEI, and ICGFP affect OEV. Following the methodology of Peasnell et al. (2001), we take a sample of firms having corporate scandals in recent years, and compare it with a control sample of firms that did not face any scandal. The analysis is conducted in two different ways. Firstly, in order to investigate any significant differences between the two samples in terms of ExCItE, OEI, and ICGFP, we perform a univariate analysis. Secondly, to investigate the factors that might determine OEV in the sample organisations, we carry out a multivariate analysis. We collect data from Datastream for a sample of 253 companies that had scandals published in the media from 28 different countries. $^{4}$ Table 2 shows details of the sample companies from different countries/industries. The largest number of scandals was recorded in the USA, as 255, from 120 companies and 30 different industries, followed by the UK, constituting 46 scandals, from 25 companies. Table 2 includes the costs associated with corporate scandals in each country, which is measured as actual or estimated penalties resulting from the lost court cases, settlements or cases not yet settled. These scandals are linked to business ethics in general, and political inducement or bribery and corruption in particular. The monetary costs arising from these scandals are over $\$ 45$ billion in one year for our sample.

[Insert Table 2 about here]

Our econometric specification requires the creation of a control sample that is not subject to any scandal. Details of our sample selection procedures are explained in Table 3 below.

[Insert Table 3 about here]

We employ the following probit regression model as our dependent variable is a binary outcome. We have chosen our sample firms through the application of a number of matching criteria, such as firm size, industry and country. Due to the nature of this study, we regard this model as the most appropriate method for this investigation.

$$
\text { OEV }=f(\text { ExCIte, OEI, ICGFP, Control Variables })
$$

Table 4 provides definitions of all the variables in the above model. OEV is a dummy variable that takes the value of 1 if a company has a scandal and 0 otherwise. A company having more than one scandal also takes the value of 1 in our probit analysis. The explanatory variables are: ExCItE, OEI, and ICGFP. We also control for leverage (LEVER), market-to-book value (MTBV) and duality (DUAL). DUAL takes the value of 1 if chairman and CEO are the same person and 0 otherwise. In addition, we collected the World Bank country-level data on rule of law, regulation 
quality, government effectiveness, strength of investors' protection and per capita GDP for each country in our sample.

\section{[Insert Table 4 about here]}

Table 5 shows details of the industrial classifications of the sample firms, where the largest number constituting 44 firms belong to the banking industry, followed by 23 firms from the insurance sector, 17 firms from the oil and gas sector, and 15 firms from the biotechnology and pharmaceutical sector. This implies the sensitivity of specific industrial sectors, which is evidenced by the highest number of incidents in these industries.

\section{[Insert Table 5 about here]}

\section{Analysis and Results}

\section{Univariate analysis}

The results of our univariate analysis are reported in Table 6. In terms of ICGFP, the results show that firms that face OEV issues have significantly larger board size as compared with firms in the control sample. This is consistent with the view that larger boards are less effective in monitoring and are also less likely to fulfil their ethical commitments. In addition, as compared with firms in the control sample, all those firms that had some kind of OEV pay significantly higher compensation to their directors. This is in accord with the assumption that higher compensation can lead to short-termism. Paying higher compensation to executives could lead to a greater emphasis on goal achievement, whereby executives will pursue organisational objectives that could lead to wealth maximisations for shareholders, but may not necessarily demonstrate a better ethical performance. Contrary to our expectations, the outcome of our univariate analysis suggests that firms that had OEV had more independent boards and had higher gender diversity on their boards. We therefore could not find support for the hypotheses that suggest that board independence and gender diversity are negatively associated with OEV. In terms of the audit committee independence, we did not find any significant differences between firms that had OEV and those of the control sample.

[Insert Table 6 about here]

The results also suggest that, as compared to firms in the control sample, firms that had OEV had a significantly higher number of board meetings. This is in line with the notion that a board of directors is subject to extensive pressures after the appearance of the news of their firm's unethical activities in media. The percentage of shares owned by the single biggest owners (SBO) is significantly higher for the control sample, which supports the assumption that large shareholders exercise significant monitoring and control, and their presence minimises the likelihood of 
OEV. Interestingly, and contrary to our expectations, firms having OEV have significantly higher commitments to business ethics. This raises some concerns about the effectiveness of corporate ethics programmes. In addition, the univariate analysis results also suggest that a significantly higher percentage of firms that had OEV had reported losses in the defect year and/or had issued profit warnings before the year of scandal.

\section{Multivariate analysis}

The results of our correlation analysis are reported in Table 7. As highlighted in Table 7 , the highest correlation coefficient is 0.43 , which is much lower than the recommended threshold of 0.80 (Field, 2009). In addition, we have also carried out the Variance Inflation Factor (VIF) test for all variables, which is generally regarded as a way of quantifying multi-collinearity in regression models. This analysis resulted in VIF values of less than 3 for all our variables, which suggests no multicollinearity among the explanatory variables of this study. On the basis of the results of the correlation and VIF analysis, we argue that multi-collinearity is not a cause of concern in our analyses.

[Insert Table 7 about here]

In order to examine the effects of ExCItE, OEI, and ICGFP on the likelihood of $\mathrm{OEV}$, we estimate a series of probit regressions, the results of which are reported in Table 8. The dependent variable in all probit regression models takes the value of 1 if a firm has a scandal and 0 otherwise. The results of all these analyses are discussed below.

\section{[Insert Table 8 about here]}

The first set of factors in our model that could determine OEV is ExCItE. The results show that the relationship between the quality of a country's legal system (represented by regulation quality and rule of law) and OEV is significantly negative. This implies that in a strong legal jurisdiction it is less likely that businesses will engage in unethical business practices. Two other country-level factors, GDP and government effectiveness, are also significantly negatively associated with OEV. The relationship between the strength of the investor protection index and $\mathrm{OEV}$ is also negative, but this relationship is statistically insignificant. In line with institutional and legitimacy theories, these results imply that strong legal systems and greater protection for shareholders' rights are important factors in the determination of OEV in different jurisdictions.

Another key determinant of OEV in our framework is OEI. With regard to OEI, we find a significantly positive association between bribery and corruption training (BCT) and OEV. This indicates that a significantly higher percentage of sample firms that allegedly engaged in unethical activities publicly disclose their 
commitment to business ethics programmes - as evidenced by a higher percentage of bribery and corruption training programmes by firms involved in unethical activities. This is consistent with the findings of Kaptein and Schwartz (2008), which report a weak or no significant impact of the corporate ethics programmes. This finding raises concerns about the effectiveness of corporate ethics programmes adopted by firms and questions the content of the programmes used by organisations. However, in relation to ethics-related training programmes, the available data do not give details about the providers of the training programmes, which may also have implications for these findings. We therefore recommend the application of independent and externally evaluated ethical assessments on an annual basis for all firms that could ensure the effectiveness of corporate ethicsrelated training programmes which may be different in content for different organisations.

With regard to ICGFP variables, the results reported in Table 8 show that board size is significantly positively associated with OEV. This result supports $H_{5}$, which hypothesises a positive relationship between board size and OEV. This is consistent with the findings of García-Sánchez et al. (2015) which suggest that larger boards are less likely to fulfil their ethical commitments. As larger boards are difficult to coordinate and are less effective in monitoring, firms with larger boards are less likely to carefully scrutinise the ethical implications of various business decisions. Consequently, firms with larger boards are more likely to be ethically vulnerable.

The results in Table 8 also indicate that board independence, audit committee independence and gender diversity are negatively associated with OEV. However, these results are statistically insignificant, which provides only partial support for hypotheses $H_{3}, H_{4}$ and $H_{6}$. The negative coefficient for single blockholder ownership and OEV confirms $H_{9}$, suggesting that large blockholders exercise a significant monitoring role in reducing the likelihood of OEV. The results also show total senior executive compensation (TSEC) as significantly positively associated with $\mathrm{OEV}$, which thus supports $H_{7}$. This finding supports the view that managerial incentives can lead to short-termism (Bebchuk and Fried, 2003). In addition, Benson and Davidson (2010) argue that executives are compensated for achieving the shareholders' value maximisation goal but not necessarily for having good relationships with the firm's stakeholders. Similarly, higher executive compensation could also encourage directors to be more focused on achieving certain targets. In this regard, existing evidence suggests that imposing achievement goals on individuals positively affects their unethical behaviour (Van Yperen et al., 2011). We therefore argue that higher compensation could encourage executives to pursue strategies that would lead to increases in shareholders' wealth and the meeting of certain targets, irrespective of considering their ethical implications. As a consequence, offering higher compensation to executives would increase OEV. 
The number of board meetings (NBM) is significantly positively associated with OEV. This implies that the boards of directors are likely to meet more frequently when the media reports negative news about their firms. This is consistent with the findings of Chen et al. (2006), who report a significantly positive association between the number of board meetings and the likelihood of accounting scandals for Chinese companies. In the context of OEV, we argue that these meetings are generally held to discuss the circumstances affecting corporate reputation after a scandal and/or to discuss the future line of action for an organisation. Consistent with the results reported in the univariate analysis, we find a significantly negative relationship between the share ownership of single largest shareholders and OEV, which implies the strong monitoring role of large shareholders in organisations.

In terms of financial performance, we find a significantly positive relationship between profit warnings issued in the year before the scandal (PW12) and OEV in the subsequent year. In Model 2, we include another measure of poor financial performance, measured by a dummy variable, PW13, which takes the value of 1 if a firm has issued profit warning during the defect year and 0 otherwise. The relationship between profit warnings in the defect year and OEV is weakly significant. Similarly, in Model 3, we include a measure for poor financial performance, represented by LOSS, which takes the value of 1 if a firm has reported losses and 0 otherwise. The relationship between LOSS and OEV is significant at the 10 percent level, suggesting that poor financial performance may trigger earnings restatement and accounting frauds. In light of all these findings, we argue that regulatory bodies should maintain a continuous surveillance of firms reporting losses and firms that issue profit warnings.

As discussed earlier we have included a number of interactions between various firm-level and country-level factors in our analysis (see models 6-10). Our results show that the interaction between bribery and corruption training and regulation quality is significantly positively associated with OEV. This would imply that, in those countries where regulation is strong, companies will offer more bribery and corruption training programmes to meet institutional requirements and gain legitimacy. However, such trainings may not be effective in stopping businesses from carrying out unethical activities. Perhaps companies may be using these training programmes as a box-ticking exercise to meet certain regulatory requirements rather than implementing processes that could prevent unethical activities. This provides further explanation for the positive relationship between bribery and corruption training programmes and OEV.

\section{Robustness tests}

Concerns have been raised in the existing literature regarding econometric specifications which fail to control for the issues arising from endogeneity (Wintoki 
et al., 2012). We use the Durbin-Wu-Hausman test of endogeneity and identify board size as an endogenous variable. As we employ cross-sectional data in this investigation, we use instrumental variables (IV) to control for endogeneity, which is a commonly used method for dealing with endogeneity problems in accounting research. In order to use a variable as an instrument, it needs to be highly correlated with the endogenous explanatory variable but should not be correlated with the error term (Larcker and Rusticus, 2010, p.186). Instrumental variable firm size (measured by logarithm of total assets) is highly correlated with board size, and it is unlikely that it can affect OEV through the error term. We therefore use firm size as an instrument for board size. The results from the IV-probit estimation are reported in Table 9, which indicates that the results are unchanged after controlling for endogeneity. In further exploring the economic significance of the regression coefficients, we also calculate marginal effect as we have used probit estimations. The marginal effect measures the probability of sample firms engaging in unethical activities. The results show that a one-unit change in profit warnings in the preceding year (PW12) increases the probability of OEV by 19\%. Similarly, the implied probability of OEV increases by a factor of 0.13 for firms providing bribery and corruption training programmes (BCT). Finally, the results from the Wald test are also insignificant, which confirms that endogeneity is not affecting our results and that our regular probit regression results reported in Table 8 are robust.

[Insert Table 9 about here]

\section{Discussion and Conclusion}

This research enhances our understanding of various firm-level and contextual factors that could determine the ethical vulnerability of organisations in different countries. We examine whether OEV arises as a result of a vacuum in organisational ethical infrastructure, corporate governance arrangements, country-level contextual factors or poor financial performance. We combine individual, organisational and institutional context as the three agencies that increase or decrease organisational ethical vulnerability.

We find that certain board characteristics are associated with OEV. For instance, firms with larger boards are more likely to be ethically vulnerable. This finding suggests that larger boards are more complex, difficult to coordinate and less effective in monitoring (Jensen, 1993). Therefore, larger boards may not be carefully scrutinising the ethical implications of various corporate decisions. This finding supports the arguments in the existing governance literature that call for limiting corporate board size to seven or eight members (Lipton and Lorsch, 1992) or 15 members (García-Sánchez et al., 2015).

In relation to board activity in the defect year, our findings show a significantly positive association between the number of board meetings and OEV. This suggests 
that board activities are likely to increase during the year of corporate scandals and that corporate response to scandals (evidenced by the number of board meetings during the defect year) is generally reactive. Under the contemporary disclosure practices in most countries, companies only report the number of board meetings in their annual reports and do not show details of issues discussed in those meetings. The outcome of our findings suggests that companies may be asked to report precisely how often business ethics-related actions are considered in their board meetings. We therefore argue that the inclusion of details about ethics-related actions in corporate board meetings will allow regulators and other stakeholders to proactively monitor corporate board activities, which might help in minimising OEV.

Another key finding of the study is related to firm-level corporate governance mechanisms, which indicates that higher senior executive compensation increases OEV. From the agency theory perspective, paying higher compensation to executives might help to align their interests with those of the shareholders. However, the framework of enlightened value maximisation suggests that shareholders' wealth maximisation is not the only priority of a firm and regards other stakeholders as the firm's strategic partners (Jensen, 2002). Our findings suggest that, although compensation may be an effective tool to encourage executives to achieve certain financial goals, it often fails to encourage them to achieve the organisation's ethical objectives. As performance-based pay is a key requirement of various corporate governance codes, this finding supports the view that strict reliance on aggressive financial goals encourages unethical corporate behaviour (Van Yperen et al., 2011). This finding has implications for regulators and practitioners, suggesting that the achievement of certain ethical performance measures could be incorporated in the existing annual targets for senior executives, which could encourage executives to make ethical considerations an integral part of their corporate strategy.

The economic implications of our findings are also significant. We show that the financial costs (fines and penalties) relating to OEV are more than $\$ 45$ billion for a sample of 253 firms in just one year. This is a huge amount and has significant implications for not only the shareholders but also other stakeholders. Companies pass on these costs to their customers, which negatively affect various stakeholders. We observe the existence of a high number of bribery and corruption training programmes in firms that have experienced ethical vulnerability. These findings thus raise questions about the effectiveness of corporate ethics training programmes and show that commitment to business ethics may not necessarily decrease OEV.

The findings of this paper identify poor financial performance as one of the key determinants of OEV. Firms issuing profit warnings or reporting losses in the preceding/current year are more likely to exhibit OEV. This suggests that poor 
financial performance may lead to short-termism and a panic response at the cost of careful consideration of the governance and ethical matters, making organisations vulnerable to corporate scandals and controversies. When firms become excessively sensitive to short-term forecasts, responses to financial analysts may trigger an intuitive rather than a rational decision-making. We argue that poor financial performance increases $\mathrm{OEV}$, and in order to mitigate this risk, responsible boards may review the sources of pressures or incentives created by rewards and performance management systems in their organisations. Therefore, regulatory bodies should develop a surveillance system which may issue early warnings about firms that are poorly performing in financial terms, and argue that such a proactive approach may help in minimising OEV. Our findings also imply that full compliance with governance regulations and codes of ethics could often provide misleading signals. For instance, fully compliant firms may not easily get caught in the regulatory surveillance system and that compliance could be used as an impression management or legitimacy tool to improve corporate image.

With regard to external context and organisational ethical infrastructure, our results suggest that country-level institutional factors are important determinants of OEV. It is generally expected that companies operating in countries with a strong rule of law, good-quality regulation, effective government infrastructure and strong GDP are less likely to be ethically vulnerable. However, the occurrence of some recent scandals in developed economies contradicts this perception. Our findings suggest that, although the quality of regulation and rule of law affect the effectiveness of organisational ethical infrastructure in different countries, organisations should also give attention to several other factors. In those countries where is rule of law, companies may offer more ethics-related training programmes to their employees. The training programmes are although intended to meet certain regulatory requirements, the real motive of firms behind such programmes may not necessarily be related to business ethics. This provides further explanation for the positive relationship between bribery and corruption-related training programmes and OEV.

These findings have implications for practitioners and policy makers. We regard business ethics as an important element of a firm's strategy and ask for certain refinements in the regulatory structure regarding the ethical awareness in firms and the structure and content of ethics-related training programmes. Why do executives become involved in unethical behaviour, which may result in substantial losses for firms in the long run? Various internal and external situational factors which may influence ethical choices made by executives have been examined in this research. However, further insights can be gained by direct examination of individual behaviour in situational context that our study has proposed. In addition, at firmlevel, the structure of ethics-related training programmes and details of who is delivering those programmes would need detailed scrutiny. For instance, the contents of an ethics-related training programme provided by a professional 
accountancy firm would be different than that offered by a management consulting firm, as the former may focus more extensively on complex accounting and taxrelated ethical issues, while the latter may provide a more holistic overview of business ethics in the corporate world. In this way, the quality of such training programmes could then be linked with OEV in a more meaningful way to understand their effectiveness.

More broadly, this study has shown that individual and organisational ethical decisions are inter-related in real life and that only partial understanding can be obtained from studying just the financial effects of ethical, social or environmental reporting. Further research is needed to validate the strength of these interrelationships between external, internal and individual factors that could make an organisation ethically vulnerable. Future studies may also explore changes in a firm's corporate governance structure (e.g. board size, composition and ownership structure) and market reactions subsequent to scandals to understand the quality of external oversight. Finally, our model of OEV could be applied in an interdisciplinary context, particularly when examining scandals in the areas of accounting, finance, marketing, human resource management, and logistics and supply chain management.

Despite the substantial contributions of this paper, the findings are subject to limitations. First, the cross-sectional nature of our data does not allow us to capture variations in firm-specific governance and financial characteristics after the scandals. Second, the role of firm-level risk management committees could have significant implications for OEV. Owing to the unavailability of such data for our cross-national sample, we are unable to capture such impact in our research. Finally, when confronted with an ethical dilemma, a board of director may conduct a costbenefit analysis, which may lead to the adoption of strategies that are profitable, yet unethical. However, investigating this aspect is not possible from our data and is therefore left to future research. 


\section{References}

Adams, M. and W. Jiang (2017). 'Do chief executives' traits affect the financial performance of risk-trading firms? Evidence from the UK insurance industry', British Journal of Management, 28, pp. 481-501.

Agrawal, A. and S. Chadha (2005). 'Corporate governance and accounting scandals', Journal of Law and Economics, 48, pp. 371-406.

Aguilera, R. V., K. Desender, M. K. Bednar and J. H. Lee (2015). 'Connecting the dots: Bringing external corporate governance into the corporate governance puzzle', Academy of Management Annals, 9, pp. 483-573.

Barraquier, A. (2011). 'Ethical behaviour in practice: Decision outcomes and strategic implications', British Journal of Management, 22, pp. S28-S46.

Bebchuk, L. A. and J. M. Fried (2003). 'Executive compensation as an agency problem', Journal of Economic Perspectives, 17, pp. 71-92.

Ben-Amar, W., C. Francoeur, T. Hafsi and R. Labelle (2013). 'What makes better boards? A closer look at diversity and ownership', British Journal of Management, 24, pp. 85-101.

Benson, B. W. and W. N. Davidson (2010). 'The relation between stakeholder management, firm value, and CEO compensation: A test of enlightened value maximization', Financial Management, 39, pp. 929-964.

Bergstresser, D. and T. Philippon (2006). 'CEO incentives and earnings management', Journal of Financial Economics, 80, pp. 511-529.

Boulouta, I. (2013). 'Hidden connections: The link between board gender diversity and corporate social performance', Journal of Business Ethics, 113, pp. 185-197.

Brenner, S. N. (1992). 'Ethics programs and their dimensions', Journal of Business Ethics, 11, pp. 391-399.

Brick, I. E. and N. Chidambaran (2010). 'Board meetings, committee structure, and firm value', Journal of Corporate Finance, 16, pp. 533-553.

Brickey, K. F. (2008). 'From boardroom to courtroom to newsroom: The media and the corporate governance scandals', Journal of Corporation Law, 33, pp. 625-663.

Brown, E. (2013). 'Vulnerability and the basis of business ethics: From fiduciary duties to professionalism', Journal of Business Ethics, 113, pp. 489-504.

Cai, Y., H. Jo and C. Pan (2012). 'Doing well while doing bad? CSR in controversial industry sectors', Journal of Business Ethics, 108, pp. 467-480.

Carroll, A. B. (1978). 'Linking business ethics to behavior in organizations', SAM Advanced Management Journal, 43, pp. 4-11.

Chen, G., M. Firth, D. N. Gao and O. M. Rui (2006). 'Ownership structure, corporate governance, and fraud: Evidence from China', Journal of Corporate Finance, 12, pp. 424-448.

Chen, J. C. and R. W. Roberts (2010). 'Toward a more coherent understanding of the organization-society relationship: A theoretical consideration for social and environmental accounting research', Journal of Business Ethics, 97, pp. 651-665.

Chhaochharia, V. and Y. Grinstein (2007). 'Corporate governance and firm value: The impact of the 2002 governance rules', Journal of Finance, 62, pp. 1789-1825.

Clegg, S., M. Kornberger and C. Rhodes (2007). 'Business ethics as ractice', British Journal of Management, 18, pp. 107-122.

Coffee Jr, J. C. (2005). 'A theory of corporate scandals: Why the USA and Europe differ', Oxford Review of Economic Policy, 21, pp. 198-211. 
Craft, J. L. (2013). 'A review of the empirical ethical decision-making literature: 20042011', Journal of Business Ethics, 117, pp. 221-259.

Denis, D. J., P. Hanouna and A. Sarin (2006). 'Is there a dark side to incentive compensation?', Journal of Corporate Finance, 12, pp. 467-488.

Deshpande, S. P., J. Joseph and V. V. Maximov (2000). 'Perceptions of proper ethical conduct of male and female Russian managers', Journal of Business Ethics, 24, pp. 179-183.

Elsaid, E. and N. D. Ursel (2017). 'Re-examining the glass cliff hypothesis using survival analysis: The case of female ceo tenure', British Journal of Management,

DOI:10.1111/1467-8551.12241.

Fama, E. F. (1980). 'Agency problems and the theory of the firm', Journal of Political Economy, 88, pp. 288-307.

Ferrell, O. C. and L. G. Gresham (1985). 'A contingency framework for understanding ethical decision making in marketing', The Journal of Marketing, pp. 87-96.

Field, A. P. (2009). Discovering Statistics Using SPSS, London, SAGE publications Ltd, UK.

García-Sánchez, I.-M., L. Rodríguez-Domínguez and J.-V. Frías-Aceituno (2015). 'Board of directors and ethics codes in different corporate governance systems', Journal of Business Ethics, 131, pp. 681-698.

Global Fraud Study (2016). Report to The Nations On Occupational Fraud and Abuse. Available at https://s3-us-west-2.amazonaws.com/acfepublic/2016-report-to-thenations.pdf.

GPO-FCIC (2011). The Financial Crisis Inquiry Report, Authorized Edition: Final Report of the National Commission on the Causes of the Financial and Economic Crisis in the United States. Washington DC: U.S. Government Printing Office.

Harrigan, K. R. (1981). 'Numbers and positions of women elected to corporate boards', Academy of Management Journal, 24, pp. 619-625.

Ibrahim, N., J. Angelidis and I. M. Tomic (2009). 'Managers' attitudes toward codes of ethics: Are there gender differences?', Journal of Business Ethics, 90, pp. 343353.

Jackson, R. W., C. M. Wood and J. J. Zboja (2013). 'The dissolution of ethical decisionmaking in organizations: A comprehensive review and model', Journal of Business Ethics, 116, pp. 233-250.

Jensen, M. and W. Meckling (1976). "Theory of the firm: Managerial behavior, agency costs and ownership structure', Journal of Financial Economics, 3, pp. 305-360.

Jensen, M. C. (1993). 'The modern industrial revolution, exit, and the failure of internal control systems', Journal of Finance, 48, pp. 831-880.

Jensen, M. C. (2002). 'Value maximization, stakeholder theory, and the corporate objective function', Business Ethics Quarterly, 12, pp. 235-256.

Jones, T. M. (1991). 'Ethical decision making by individuals in organizations: An issuecontingent model', Academy of Management Review, 16, pp. 366-395.

Kaptein, M. and M. S. Schwartz (2008). 'The effectiveness of business codes: A critical examination of existing studies and the development of an integrated research model', Journal of Business Ethics, 77, pp. 111-127.

Kohlberg, L. (1973). 'The claim to moral adequacy of a highest stage of moral judgment', The Journal of Philosophy, 70, pp. 630-646.

La Porta, R., F. Lopez-de-Silanes, A. Shleifer and R. W. Vishny (1998). 'Law and finance', Journal of Political Economy, 106, pp. 1113-1155. 
Larcker, D. F. and T. O. Rusticus (2010). 'On the use of instrumental variables in accounting research', Journal of Accounting and Economics, 49, pp. 186-205.

Lipton, M. and J. Lorsch (1992). 'A modest proposal for improved corporate governance', Business Lawyer., 48, pp. 59-77.

Lopez, T. B., B. J. Babin and C. Chung (2009). 'Perceptions of ethical work climate and person-organization fit among retail employees in Japan and the US: A crosscultural scale validation', Journal of Business Research, 62, pp. 594-600.

Mangena, M., V. Tauringana and E. Chamisa (2012). 'Corporate boards, ownership structure and firm performance in an environment of severe political and economic crisis', British Journal of Management, 23, pp. S23-S41.

Matthews, J. B., K. E. Goodpaster and L. L. Nash (1985). Policies and Persons a Casebook in Business Ethics, Mcgraw-Hill New York.

McDevitt, R., C. Giapponi and C. Tromley (2007). 'A model of ethical decision making: The integration of process and content', Journal of Business ethics, 73, pp. 219229.

Misangyi, V. F. and A. G. Acharya (2014). 'Substitutes or complements? A configurational examination of corporate governance mechanisms', Academy of Management Journal, 57, pp. 1681-1705.

Musteen, M., D. K. Datta and B. Kemmerer (2010). 'Corporate reputation: Do board characteristics matter?', British Journal of Management, 21, pp. 498-510.

Nash, L. L. (1990). Good intentions aside: A manager's guide to resolving ethical problems, Harvard Business Press, Boston, USA.

Ntim, C. G. and T. Soobaroyen (2013). 'Corporate governance and performance in socially responsible corporations: New empirical insights from a NeoInstitutional framework', Corporate Governance: An International Review, 21, pp. 468-494.

Pae, J. and T. Choi (2011). 'Corporate governance, commitment to business ethics, and firm valuation: Evidence from the Korean stock market', Journal of Business Ethics, 100, pp. 323-348.

Peasnell, K. V., P. F. Pope and S. Young (2001). 'The characteristics of firms subject to adverse rulings by the Financial Reporting Review Panel', Accounting and Business Research, 31, pp. 291-311.

Post, C. and K. Byron (2015). 'Women on boards and firm financial performance: A meta-analysis', Academy of Management Journal, 58, pp. 1546-1571.

Rodriguez-Dominguez, L., I. Gallego-Alvarez and I. M. Garcia-Sanchez (2009). 'Corporate governance and codes of ethics', Journal of Business Ethics, 90, pp. 187-202.

Schwartz, M. S. (2016). 'Ethical decision-making theory: An integrated approach', Journal of Business Ethics, 139, pp. 755-776.

Shleifer, A. and R. W. Vishny (1986). 'Large Shareholders and Corporate Control', Journal of Political Economy, 94, pp. 461-488.

Shleifer, A. and R. W. Vishny (1997). 'A survey of corporate governance', Journal of Finance, 52, pp. 737-783.

Simga-Mugan, C., B. A. Daly, D. Onkal and L. Kavut (2005). 'The influence of nationality and gender on ethical sensitivity: An application of the issuecontingent model', Journal of Business Ethics, 57, pp. 139-159. 
Singh, S., N. Tabassum, T. K. Darwish and G. Batsakis (2017). 'Corporate governance and Tobin's Q as a measure of organizational performance', British Journal of Management, DOI:10.1111/1467-8551.12237.

Skovoroda, R. and A. Bruce (2017). 'Shifting the goalposts? Analysing changes to performance peer groups used to determine the remuneration of FTSE 100 CEOs', British Journal of Management, 28, pp. 265-279.

Tenbrunsel, A. E., K. Smith-Crowe and E. E. Umphress (2003). 'Building houses on rocks: The role of the ethical infrastructure in organizations', Social Justice Research, 16, pp. 285-307.

Thomsen, S., T. Pedersen and H. K. Kvist (2006). 'Blockholder ownership: Effects on firm value in market and control based governance systems', Journal of Corporate Finance, 12, pp. 246-269.

Trevino, L. K. (1986). 'Ethical decision making in organizations: A person-situation interactionist model', Academy of Management Review, 11, pp. 601-617.

Uzun, H., S. H. Szewczyk and R. Varma (2004). 'Board composition and corporate fraud', Financial Analysts Journal, 60, pp. 33-43.

Vafeas, N. (1999). 'Board meeting frequency and firm performance', Journal of Financial Economics, 53, pp. 113-142.

Van Yperen, N. W., M. R. W. Hamstra and M. Van der Klauw (2011). 'To win, or not to lose, at any cost: The impact of achievement goals on cheating', British Journal of Management, 22, pp. S5-S15.

Wang, J. and K. Ye (2015). 'Media coverage and firm valuation: Evidence from China', Journal of Business Ethics, 127, pp. 501-511.

Wintoki, M. B., J. S. Linck and J. M. Netter (2012). 'Endogeneity and the dynamics of internal corporate governance', Journal of Financial Economics, 105, pp. 581606.

Yermack, D. (1996). 'Higher market valuation of companies with a small board of directors', Journal of Financial Economics, 40, pp. 185-211. 
Table 2 Sample characteristics

\begin{tabular}{|c|c|c|c|c|c|c|}
\hline Countries & $\begin{array}{l}\text { No. of } \\
\text { Industries }\end{array}$ & $\begin{array}{c}\text { No. of } \\
\text { Companies }\end{array}$ & $\begin{array}{l}\text { No. of } \\
\text { Scandals }\end{array}$ & $\begin{array}{l}\% \text { of scandals } \\
\text { in each country }\end{array}$ & $\begin{array}{l}\text { Costs of Corporate } \\
\text { scandals ( } \$ \\
\text { millions) }\end{array}$ & $\begin{array}{l}\text { Cost in each } \\
\text { country as a \% } \\
\text { of total cost }\end{array}$ \\
\hline Australia & 4 & 9 & 13 & $2.863 \%$ & 30.98 & $0.068 \%$ \\
\hline Belgium & 1 & 1 & 2 & $0.441 \%$ & 3.25 & $0.007 \%$ \\
\hline Brazil & 1 & 1 & 1 & $0.220 \%$ & NA & NA \\
\hline Canada & 8 & 10 & 11 & $2.423 \%$ & 336.14 & $0.743 \%$ \\
\hline China & 3 & 4 & 7 & $1.542 \%$ & 8.27 & $0.018 \%$ \\
\hline Denmark & 2 & 2 & 2 & $0.441 \%$ & NA & NA \\
\hline France & 9 & 10 & 15 & $3.304 \%$ & 412.53 & $0.911 \%$ \\
\hline Germany & 8 & 11 & 20 & $4.405 \%$ & 1984.93 & $4.385 \%$ \\
\hline Greece & 1 & 1 & 1 & $0.220 \%$ & 0.09 & $0.000 \%$ \\
\hline Hong Kong & 2 & 2 & 5 & $1.101 \%$ & 249.00 & $0.550 \%$ \\
\hline India & 5 & 7 & 10 & $2.203 \%$ & 1110.40 & $2.453 \%$ \\
\hline Ireland & 1 & 1 & 1 & $0.220 \%$ & 0.12 & $0.000 \%$ \\
\hline Israel & 2 & 2 & 2 & $0.441 \%$ & 1.65 & $0.004 \%$ \\
\hline Italy & 5 & 5 & 6 & $1.322 \%$ & 0.78 & $0.002 \%$ \\
\hline Japan & 4 & 5 & 5 & $1.101 \%$ & 632.94 & $1.398 \%$ \\
\hline Malaysia & 2 & 2 & 2 & $0.441 \%$ & NA & NA \\
\hline Mexico & 2 & 2 & 2 & $0.441 \%$ & 10.76 & $0.024 \%$ \\
\hline Netherlands & 6 & 6 & 7 & $1.542 \%$ & 26.34 & $0.058 \%$ \\
\hline Norway & 2 & 2 & 2 & $0.441 \%$ & 16.48 & $0.036 \%$ \\
\hline Russia & 1 & 1 & 2 & $0.441 \%$ & 88.92 & $0.196 \%$ \\
\hline South Africa & 4 & 4 & 4 & $0.881 \%$ & 32.79 & $0.072 \%$ \\
\hline South Korea & 5 & 8 & 9 & $1.982 \%$ & 0.00 & $0.000 \%$ \\
\hline Spain & 1 & 1 & 1 & $0.220 \%$ & NA & NA \\
\hline Sweden & 3 & 3 & 5 & $1.101 \%$ & 9.26 & $0.020 \%$ \\
\hline Switzerland & 5 & 6 & 16 & $3.524 \%$ & 435.31 & $0.962 \%$ \\
\hline Thailand & 2 & 2 & 2 & $0.441 \%$ & 1.27 & $0.003 \%$ \\
\hline \multicolumn{7}{|l|}{ United } \\
\hline Kingdom & 12 & 25 & 46 & $10.132 \%$ & 3093.48 & $6.834 \%$ \\
\hline United States & 30 & 120 & 255 & $56.167 \%$ & 36782.99 & $81.255 \%$ \\
\hline Total & 131 & 253 & 454 & $100 \%$ & 45268.69 & $100 \%$ \\
\hline
\end{tabular}


Step 1: We searched for those companies having scandals published in media from a total of 3,898 companies in the Datastream 'Asset4 Universe' between 2002 and 2015.

Step 2: We identified 520 firms having scandals published in media from a total of 3,898 companies

Step 3: We excluded 200 firms that were accused by media but were not yet penalised by any court of law/regulatory body or where no case was initiated by a court of law

Initial sample

Step 4: A corresponding control firm was chosen from the same industry and country. Following Peasnell, Pope and Young (2001), the total assets of a matched (control) firm should be in the range of $\pm 25 \%$ of the total assets of a defect firm which resulted in the deletion of 67 firms from the sample [as those firms did not fulfil the matching criterion].

Step 5: Our final sample comprises 253 firms from 28 countries for the year 2013 . The year 2013 was chosen as the sample year, because the highest number of corporate scandals have been reported during this year.

\begin{tabular}{lcrr}
\hline Panel B - Firm Size & & & \\
\hline Variable & Firms having scandals & Control sample & p-value for difference \\
\hline Market-to-book value (MTBV) & 2.10232 & 2.239167 & 0.8171 \\
\hline
\end{tabular}

\footnotetext{
A paired sample t-test is used to evaluate the differences in means for the market-to-book value of equity for firms having scandals and for the control sample.

*Firm Size is measured as the market-to-book value of equity.
} 


\begin{tabular}{|c|c|c|}
\hline Variables & Definition & $\begin{array}{l}\text { Source/Datastream } \\
\text { Code }\end{array}$ \\
\hline $\begin{array}{l}\text { Organisational Ethical Vulnerability } \\
\text { (OEV) }\end{array}$ & $\begin{array}{l}\text { A dummy variable that takes the value of } 1 \text { if a company has a } \\
\text { scandal published in the media linked to business ethics in general, } \\
\text { political contributions or bribery and corruption, otherwise } 0 .\end{array}$ & SOCODP058 \\
\hline \multicolumn{3}{|c|}{ External Context and Impact Enablers (ExCItE) } \\
\hline Regulation quality (REGQUA) & $\begin{array}{l}\text { The index measures how governments formulate and implement } \\
\text { sound policies and regulations that permit and promote private } \\
\text { sector development. }\end{array}$ & World Bank indicator \\
\hline $\begin{array}{l}\text { Strength of investor protection index } \\
\text { (SIPI) }\end{array}$ & $\begin{array}{l}\text { This index is an average of three indices: the extent of disclosure } \\
\text { index, the extent of director liability index, and the ease of } \\
\text { shareholder suit index. The index ranges from } 0 \text { (little to no } \\
\text { investor protection) to } 10 \text { (greater investor protection). }\end{array}$ & World Bank indicator \\
\hline Rule of Law (RULEOFLAW) & $\begin{array}{l}\text { The index measures the quality of contract enforcement, property } \\
\text { rights, the police, and the courts, as well as the likelihood of crime } \\
\text { and violence. Values vary from } 0 \text { (non-existent) to } 100 \text { (excellent). }\end{array}$ & World Bank indicator \\
\hline $\begin{array}{l}\text { Government effectiveness } \\
\text { (GOVEFECT) }\end{array}$ & $\begin{array}{l}\text { The index which ranges from } 0 \text { to } 100 \text { measures the quality of } \\
\text { public services, the quality of the civil service and the degree of its } \\
\text { independence from political pressures. }\end{array}$ & World Bank indicator \\
\hline GDP per capita (LOGGDP) & Logarithm of per capita GDP in US dollars. & World Bank indicator \\
\hline \multicolumn{3}{|l|}{ Organisational Ethical Infrastructure (OEI) } \\
\hline Bribery and corruption training $(\mathrm{BCT})$ & $\begin{array}{l}\text { Does the company train its employees on the prevention of } \\
\text { corruption and bribery? } 1 \text { if yes, otherwise } 0 .\end{array}$ & SOCODP008 \\
\hline $\begin{array}{l}\text { Explicit commitments to business ethics } \\
\text { (ECBI) }\end{array}$ & $\begin{array}{l}\text { Does the company have appropriate communication tools (whistle } \\
\text { blower, ombudsman, suggestion box, ethics hotline, newsletter, } \\
\text { website, etc.) to improve general business ethics? } 1 \text { if yes, } \\
\text { otherwise } 0 \text {. }\end{array}$ & SOCODP0101 \\
\hline Skills (SKILL) & $\begin{array}{l}\text { The percentage of board members who have either an industry- } \\
\text { specific background or a strong financial background. }\end{array}$ & CGBSO04S \\
\hline \multicolumn{3}{|c|}{ Internal Corporate Governance and Financial Performance (ICGFP) } \\
\hline Board size (BSIZE) & The total number of board members at the end of the fiscal year. & CGBSDP060 \\
\hline Non-executive directors (NEDs) & Percentage of non-executive board members. & CGBSO06V \\
\hline Number of board meetings (NBM) & The number of board meetings during the year. & CGBFDP024 \\
\hline Gender diversity (GD) & Percentage of women on the board of directors. & CGBSO17V \\
\hline $\begin{array}{l}\text { Total senior executives' compensation } \\
\text { (TSEC) }\end{array}$ & $\begin{array}{l}\text { Logarithm of the total compensation paid to all senior executives } \\
\text { (if total aggregate is reported by the company). }\end{array}$ & CGCPDP054 \\
\hline $\begin{array}{l}\text { Single largest/biggest shareholder/owner } \\
\text { (SBO) }\end{array}$ & $\begin{array}{l}\text { The percentage ownership of the single largest/biggest owner (by } \\
\text { voting power) having shares ownership } \geq 5 \% \text {. }\end{array}$ & CGSRDP045 \\
\hline Audit committee independence (ACI) & $\begin{array}{l}\text { Percentage of non-executive board member on the audit } \\
\text { committee. }\end{array}$ & CGBFDP018 \\
\hline Profit warnings (PW12) & $\begin{array}{l}1 \text { if a firm has issued a profit warning in the year before the } \\
\text { scandal, otherwise } 0 \text {. }\end{array}$ & ECSLDP059 \\
\hline Profit warnings (PW13) & $\begin{array}{l}1 \text { if a firm has issued a profit warning during the defect year, } \\
\text { otherwise } 0 \text {. }\end{array}$ & ECSLDP059 \\
\hline Loss in the defect year (LOSS) & $\begin{array}{l}1 \text { if the company has reported loss in the year of scandal, otherwise } \\
0 .\end{array}$ & \\
\hline Costs of corporate scandals (CCS) & $\begin{array}{l}\text { All real or estimated penalties, fines from lost court cases, } \\
\text { settlements or cases not yet settled regarding these scandals linked } \\
\text { to business ethics in general, political contributions or bribery and } \\
\text { corruption. }\end{array}$ & SOCODP059 \\
\hline \multicolumn{3}{|l|}{ Control Variables } \\
\hline VER) & A firm's total debt divided by its total assets. & WC03255/WC02999 \\
\hline Market-to-book value (MTBV) & $\begin{array}{l}\text { This is defined as the market value of the ordinary (common) } \\
\text { equity divided by the balance sheet value of the ordinary } \\
\text { (common) equity. }\end{array}$ & MTBV \\
\hline Dual (DUAL) & 1 if chairman and CEO are the same person, 0 otherwise. & CGBSO09V \\
\hline
\end{tabular}


Table 5 Industrial composition of the sample firms

\begin{tabular}{|c|c|c|}
\hline Industry name & No. of companies & $\%$ \\
\hline Aerospace/Defence & 11 & 4.35 \\
\hline Air Freight/Courier Services & 1 & 0.40 \\
\hline Airline Services & 1 & 0.40 \\
\hline Automobiles/Auto Parts & 4 & 1.58 \\
\hline Banking Services & 44 & 17.39 \\
\hline Beverages & 2 & 0.79 \\
\hline Biotechnology/Medical Research & 3 & 1.19 \\
\hline Biotechnology/Pharmaceuticals & 15 & 5.93 \\
\hline Chemicals & 1 & 0.40 \\
\hline Coal & 2 & 0.79 \\
\hline Commercial Services/Supplies & 6 & 2.37 \\
\hline Communications Equipment & 1 & 0.40 \\
\hline Construction/Engineering/Materials & 7 & 2.77 \\
\hline Electric Utilities & 5 & 1.98 \\
\hline Energy-Related Equipment/Services & 7 & 2.77 \\
\hline Food/Drug Retailing & 4 & 1.58 \\
\hline Food/Tobacco & 10 & 3.95 \\
\hline Gas Utilities & 2 & 0.79 \\
\hline Healthcare Equipment/Supplies & 4 & 1.58 \\
\hline Healthcare Providers/Services & 6 & 2.37 \\
\hline Hotels/Entertainment Services & 6 & 2.37 \\
\hline Household Goods & 2 & 0.79 \\
\hline Industrial Conglomerates & 8 & 3.16 \\
\hline Insurance & 23 & 9.09 \\
\hline Investment Services & 11 & 4.35 \\
\hline Machinery/Equipment/Components & 6 & 2.37 \\
\hline Media/Publishing & 7 & 2.77 \\
\hline Metal/Mining & 11 & 4.35 \\
\hline Oil and Gas & 17 & 6.72 \\
\hline Personal/Household Products/Services & 3 & 1.19 \\
\hline Rails/Roads Transportation & 1 & 0.40 \\
\hline Real Estate Operations & 1 & 0.40 \\
\hline Retailers - Diversified & 3 & 1.19 \\
\hline Retailers - Specialty & 2 & 0.79 \\
\hline Semiconductors/Semiconductor Equipment & 2 & 0.79 \\
\hline Software/IT Services & 3 & 1.19 \\
\hline Telecommunications Services & 11 & 4.35 \\
\hline Total & 253 & 100 \\
\hline
\end{tabular}


Table 6 Univariate (mean) comparisons of companies having scandals and control sample of matchedpairs for the defect year 2013

\begin{tabular}{lcccc} 
Variables & Observations & $\begin{array}{c}\text { Firms having } \\
\text { scandals }\end{array}$ & $\begin{array}{c}\text { Control } \\
\text { sample }\end{array}$ & $\begin{array}{c}\text { p-value for } \\
\text { difference }\end{array}$ \\
\hline Internal Corporate Governance and Financial Performance $($ ICGFP) & & \\
BSIZE & 497 & 12.30435 & 10.63934 & $<0.001$ \\
NEDs & 497 & 81.21787 & 78.46889 & 0.0316 \\
NBM & 477 & 9.995951 & 8.83913 & 0.0051 \\
GD & 497 & 17.75802 & 14.12119 & 0.0001 \\
SBO & 427 & 16.27077 & 20.74534 & 0.013 \\
TSEC & 468 & 7.345119 & 7.073186 & $<0.001$ \\
ACI & 502 & 99.3083 & 98.59438 & 0.1469 \\
PW12 & 492 & 0.4347826 & 0.1818182 & $<0.001$ \\
LOSS & 506 & 0.1225296 & 0.0671937 & 0.0337 \\
Organisational Ethical Infrastructure & $($ OEI) & & & \\
BCT & 506 & 0.7272727 & 0.4347826 & $<0.001$ \\
ECBI & 505 & 0.8695652 & 0.7579365 & 0.0012 \\
SKILL & 505 & 43.99631 & 49.85253 & 0.0159 \\
Control variables & & & & \\
LEVER & 506 & 0.2354032 & 0.247459 & 0.4107 \\
DUAL & 506 & 0.4071146 & 0.3320158 & 0.0804 \\
& & & & \\
\hline
\end{tabular}

Note: Definitions of the variables are reported in Table 4 
Table 7 Correlation matrix

\begin{tabular}{|c|c|c|c|c|c|c|c|c|c|c|c|c|c|c|c|c|c|c|}
\hline & OEV & BSIZE & NEDs & NBM & GD & DUAL & SBO & TSEC & ACI & BCT & ECBI & LEVER & PW12 & LOSS & REGQUA & SIPI & SKILL & MTBV \\
\hline OEV & 1.00 & & & & & & & & & & & & & & & & & \\
\hline BSIZE & 0.25 & 1.00 & & & & & & & & & & & & & & & & \\
\hline NEDs & 0.10 & 0.07 & 1.00 & & & & & & & & & & & & & & & \\
\hline NBM & 0.13 & -0.05 & -0.01 & 1.00 & & & & & & & & & & & & & & \\
\hline GD & 0.17 & 0.14 & 0.27 & 0.05 & 1.00 & & & & & & & & & & & & & \\
\hline DUAL & 0.08 & -0.05 & 0.30 & -0.10 & -0.02 & 1.00 & & & & & & & & & & & & \\
\hline SBO & -0.12 & 0.11 & -0.17 & 0.01 & -0.16 & -0.16 & 1.00 & & & & & & & & & & & \\
\hline TSEC & 0.28 & 0.16 & 0.29 & -0.06 & 0.16 & 0.21 & -0.38 & 1.00 & & & & & & & & & & \\
\hline ACI & 0.06 & 0.10 & 0.25 & -0.02 & 0.16 & 0.14 & -0.08 & 0.28 & 1.00 & & & & & & & & & \\
\hline BCT & 0.30 & 0.18 & 0.09 & 0.03 & 0.21 & 0.04 & -0.06 & 0.29 & 0.11 & 1.00 & & & & & & & & \\
\hline ECBI & 0.14 & -0.06 & 0.35 & 0.00 & 0.13 & 0.16 & -0.14 & 0.39 & 0.09 & 0.23 & 1.00 & & & & & & & \\
\hline LEVER & -0.04 & -0.04 & 0.04 & 0.07 & 0.02 & 0.03 & 0.02 & -0.08 & 0.00 & 0.00 & 0.01 & 1.00 & & & & & & \\
\hline PW12 & 0.27 & 0.10 & 0.20 & -0.03 & 0.18 & 0.04 & -0.13 & 0.30 & 0.09 & 0.24 & 0.21 & 0.04 & 1.00 & & & & & \\
\hline LOSS & 0.09 & -0.05 & 0.04 & 0.16 & -0.04 & -0.02 & -0.01 & -0.08 & 0.06 & 0.03 & 0.07 & 0.14 & 0.06 & 1.00 & & & & \\
\hline REGQUA & 0.01 & -0.10 & 0.12 & 0.07 & 0.27 & -0.01 & -0.38 & 0.41 & 0.18 & 0.13 & 0.19 & -0.12 & 0.11 & -0.04 & 1.00 & & & \\
\hline SIPI & 0.01 & -0.01 & 0.06 & 0.07 & 0.14 & -0.09 & -0.10 & 0.01 & 0.11 & 0.07 & 0.09 & 0.02 & -0.07 & 0.03 & 0.22 & 1.00 & & \\
\hline SKILL & -0.11 & -0.29 & -0.17 & 0.05 & -0.11 & -0.03 & -0.05 & -0.05 & -0.06 & -0.13 & -0.03 & -0.12 & -0.18 & -0.03 & 0.07 & 0.09 & 1.00 & \\
\hline MTBV & -0.11 & 0.43 & 0.01 & -0.04 & -0.03 & -0.03 & 0.04 & -0.06 & 0.00 & -0.05 & 0.01 & 0.00 & -0.02 & 0.00 & -0.02 & -0.01 & 0.02 & 1.00 \\
\hline
\end{tabular}


Table 8 The impact of country-level and firm-level factors on Organisational Ethical Vulnerability

\begin{tabular}{|c|c|c|c|c|c|c|c|c|c|c|}
\hline Variables & 1 & 2 & 3 & 4 & 5 & 6 & 7 & 8 & 9 & 10 \\
\hline \multicolumn{11}{|l|}{ ExCItE Variables } \\
\hline REGQUA & $\begin{array}{c}-0.0246 * * * \\
(0.00680)\end{array}$ & $\begin{array}{c}-0.0248 * * * \\
(0.00685)\end{array}$ & $\begin{array}{c}-0.0249 * * * \\
(0.00687)\end{array}$ & & & $\begin{array}{l}-0.0160^{*} \\
(0.00859)\end{array}$ & $\begin{array}{c}-0.0245 * * * \\
(0.00680)\end{array}$ & & & $\begin{array}{c}-0.0262 * * * * \\
(0.00685)\end{array}$ \\
\hline SIPI & $\begin{array}{l}0.0336 \\
(0.103)\end{array}$ & $\begin{array}{c}-0.00639 \\
(0.100)\end{array}$ & $\begin{array}{c}-0.000429 \\
(0.100)\end{array}$ & $\begin{array}{l}-0.0297 \\
(0.0990)\end{array}$ & $\begin{array}{l}-0.0679 \\
(0.102)\end{array}$ & $\begin{array}{l}0.0334 \\
(0.102)\end{array}$ & $\begin{array}{c}0.156 \\
(0.125)\end{array}$ & $\begin{array}{l}-0.0105 \\
(0.101)\end{array}$ & $\begin{array}{l}0.0159 \\
(0.102)\end{array}$ & $\begin{array}{l}0.0342 \\
(0.103)\end{array}$ \\
\hline RULEOFLAW & & & & $\begin{array}{c}-0.0202 * * * \\
(0.00677)\end{array}$ & & & & & $\begin{array}{c}-0.0216^{* * *} \\
(0.0101)\end{array}$ & \\
\hline GOVEFFECT & & & & & & & & $\begin{array}{c}-0.0287 * * \\
(0.0117)\end{array}$ & & \\
\hline LOGGDP & & & & & $\begin{array}{c}-1.123 * * * \\
(0.29)\end{array}$ & & & & & \\
\hline \multicolumn{11}{|l|}{ OEI Variables } \\
\hline BCT & $\begin{array}{c}0.380 * * \\
(0.158)\end{array}$ & $\begin{array}{c}0.426 * * * \\
(0.155)\end{array}$ & $\begin{array}{c}0.434 * * * \\
(0.155)\end{array}$ & $\begin{array}{c}0.417 * * * \\
(0.155)\end{array}$ & $\begin{array}{l}0.306^{*} \\
(0.159)\end{array}$ & $\begin{array}{c}0.384 * * \\
(0.157)\end{array}$ & $\begin{array}{c}0.380 * * \\
(0.158)\end{array}$ & $\begin{array}{c}0.383 * * \\
(0.156)\end{array}$ & $\begin{array}{c}0.394 * * \\
(0.155)\end{array}$ & \\
\hline ECBI & $\begin{array}{l}0.0238 \\
(0.223)\end{array}$ & $\begin{array}{l}0.0605 \\
(0.221)\end{array}$ & $\begin{array}{c}-0.00170 \\
(0.223)\end{array}$ & $\begin{array}{l}0.0192 \\
(0.221)\end{array}$ & $\begin{array}{l}0.0453 \\
(0.224)\end{array}$ & $\begin{array}{l}0.0119 \\
(0.222)\end{array}$ & $\begin{array}{l}0.0174 \\
(0.222)\end{array}$ & $\begin{array}{l}-0.287 \\
(1.192)\end{array}$ & $\begin{array}{l}-0.234 \\
(1.030)\end{array}$ & $\begin{array}{l}0.0342 \\
(0.222)\end{array}$ \\
\hline SKILL & $\begin{array}{c}-0.00317 \\
(0.00288)\end{array}$ & $\begin{array}{l}-0.00445 \\
(0.00283)\end{array}$ & $\begin{array}{l}-0.00475^{*} \\
(0.00281)\end{array}$ & $\begin{array}{l}-0.00462 * \\
(0.00280)\end{array}$ & $\begin{array}{l}-0.00305 \\
(0.00290)\end{array}$ & $\begin{array}{l}-0.00307 \\
(0.00288)\end{array}$ & $\begin{array}{c}-0.00319 \\
(0.00288)\end{array}$ & $\begin{array}{l}-0.00241 \\
(0.00285)\end{array}$ & $\begin{array}{l}-0.00252 \\
(0.00285)\end{array}$ & $\begin{array}{l}-0.00321 \\
(0.00288)\end{array}$ \\
\hline \multicolumn{11}{|l|}{ ICGFP Variables } \\
\hline BSIZE & $\begin{array}{c}0.0578 * * \\
(0.0241)\end{array}$ & $\begin{array}{c}0.0558 * * \\
(0.0241)\end{array}$ & $\begin{array}{c}0.0566 * * \\
(0.0239)\end{array}$ & $\begin{array}{c}0.0604 * * \\
(0.0239)\end{array}$ & $\begin{array}{c}0.0532 * * \\
(0.0244)\end{array}$ & $\begin{array}{c}0.0573 * * \\
(0.0241)\end{array}$ & $\begin{array}{c}0.0581 * * \\
(0.0241)\end{array}$ & $\begin{array}{c}0.0580 * * \\
(0.0240)\end{array}$ & $\begin{array}{c}0.0593 * * \\
(0.0240)\end{array}$ & $\begin{array}{c}0.0583 * * \\
(0.0241)\end{array}$ \\
\hline NED & $\begin{array}{c}-0.0113 \\
(0.00692)\end{array}$ & $\begin{array}{c}-0.0107 \\
(0.00687)\end{array}$ & $\begin{array}{c}-0.0103 \\
(0.00685)\end{array}$ & $\begin{array}{l}-0.00917 \\
(0.00681)\end{array}$ & $\begin{array}{l}-0.00898 \\
(0.00697)\end{array}$ & & & & & $\begin{array}{c}-0.0113 \\
(0.00693)\end{array}$ \\
\hline NBM & $\begin{array}{c}0.0410 * * \\
(0.0177)\end{array}$ & $\begin{array}{c}0.0390 * * \\
(0.0174)\end{array}$ & $\begin{array}{c}0.0358 * * \\
(0.0175)\end{array}$ & $\begin{array}{l}0.0323 * \\
(0.0173)\end{array}$ & $\begin{array}{c}0.0465^{* * * *} \\
(0.0179)\end{array}$ & $\begin{array}{c}0.0409 * * \\
(0.0177)\end{array}$ & $\begin{array}{c}0.0414 * * \\
(0.0177)\end{array}$ & $\begin{array}{c}0.0375 * * \\
(0.0174)\end{array}$ & $\begin{array}{c}0.0353 * * \\
(0.0174)\end{array}$ & $\begin{array}{c}0.0409 * * \\
(0.0176)\end{array}$ \\
\hline GD & $\begin{array}{c}0.0117 \\
(0.00759)\end{array}$ & $\begin{array}{c}0.0110 \\
(0.00757)\end{array}$ & $\begin{array}{c}0.0140 * \\
(0.00752)\end{array}$ & $\begin{array}{c}0.0126^{*} \\
(0.00747)\end{array}$ & $\begin{array}{c}0.0119 \\
(0.00760)\end{array}$ & $\begin{array}{c}0.0116 \\
(0.00760)\end{array}$ & $\begin{array}{c}0.0114 \\
(0.00757)\end{array}$ & $\begin{array}{c}0.00960 \\
(0.00751)\end{array}$ & $\begin{array}{c}0.00887 \\
(0.00749)\end{array}$ & $\begin{array}{c}0.0118 \\
(0.00760)\end{array}$ \\
\hline DUAL & $\begin{array}{l}0.0920 \\
(0.163)\end{array}$ & $\begin{array}{l}0.0777 \\
(0.162)\end{array}$ & $\begin{array}{l}0.0924 \\
(0.162)\end{array}$ & $\begin{array}{c}0.152 \\
(0.161)\end{array}$ & $\begin{array}{l}0.173 \\
(0.163)\end{array}$ & $\begin{array}{l}0.0872 \\
(0.163)\end{array}$ & $\begin{array}{l}0.0908 \\
(0.163)\end{array}$ & $\begin{array}{l}0.0762 \\
(0.156)\end{array}$ & $\begin{array}{l}0.0793 \\
(0.155)\end{array}$ & $\begin{array}{l}0.0980 \\
(0.162)\end{array}$ \\
\hline SBO & $\begin{array}{c}-0.00896 * * \\
(0.00452)\end{array}$ & $\begin{array}{c}-0.00886 * * \\
(0.00443)\end{array}$ & $\begin{array}{l}-0.00871 * \\
(0.00445)\end{array}$ & $\begin{array}{c}-0.00887 * * \\
(0.00448)\end{array}$ & $\begin{array}{l}-0.00872 * \\
(0.00451)\end{array}$ & $\begin{array}{l}-0.00872 * \\
(0.00450)\end{array}$ & $\begin{array}{c}-0.00888 * * \\
(0.00451)\end{array}$ & $\begin{array}{l}-0.00766^{*} \\
(0.00443)\end{array}$ & $\begin{array}{c}-0.00802 * \\
(0.00446)\end{array}$ & $\begin{array}{r}-0.00875^{*} \\
(0.00451)\end{array}$ \\
\hline TSEC & $\begin{array}{c}0.839 * * * \\
(0.219)\end{array}$ & $\begin{array}{c}0.914 * * * \\
(0.218)\end{array}$ & $\begin{array}{c}1.018 * * * \\
(0.222)\end{array}$ & $\begin{array}{c}0.910 * * * \\
(0.213)\end{array}$ & $\begin{array}{c}0.998 * * * \\
(0.232)\end{array}$ & $\begin{array}{c}0.833 * * * \\
(0.218)\end{array}$ & $\begin{array}{c}0.841 * * * \\
(0.219)\end{array}$ & $\begin{array}{c}0.788 * * * \\
(0.215)\end{array}$ & $\begin{array}{c}0.712 * * * \\
(0.209)\end{array}$ & $\begin{array}{c}0.830 * * * \\
(0.219)\end{array}$ \\
\hline ACI & $\begin{array}{c}-0.000977 \\
(0.0139)\end{array}$ & $\begin{array}{l}-0.00220 \\
(0.0137)\end{array}$ & $\begin{array}{l}-0.00425 \\
(0.0138)\end{array}$ & $\begin{array}{l}-0.00736 \\
(0.0139)\end{array}$ & $\begin{array}{l}0.00169 \\
(0.0140)\end{array}$ & $\begin{array}{l}-0.00179 \\
(0.0138)\end{array}$ & $\begin{array}{l}-0.00153 \\
(0.0138)\end{array}$ & $\begin{array}{l}-0.00599 \\
(0.0133)\end{array}$ & $\begin{array}{c}-0.00826 \\
(0.0134)\end{array}$ & $\begin{array}{c}-3.14 \mathrm{e}-05 \\
(0.0139)\end{array}$ \\
\hline PW12 & $\begin{array}{c}0.566 * * * \\
(0.165)\end{array}$ & & & & $\begin{array}{c}0.581 * * * \\
(0.166)\end{array}$ & $\begin{array}{c}0.564 * * * \\
(0.165)\end{array}$ & $\begin{array}{c}0.565 * * * \\
(0.165)\end{array}$ & $\begin{array}{c}0.540 * * * \\
(0.164)\end{array}$ & $\begin{array}{c}0.541 * * * \\
(0.163)\end{array}$ & $\begin{array}{c}0.573 * * * \\
(0.164)\end{array}$ \\
\hline
\end{tabular}




\begin{tabular}{|c|c|c|c|c|c|c|c|c|c|c|}
\hline PW13 & & $\begin{array}{l}0.318^{*} \\
(0.172)\end{array}$ & & & & & & & & \\
\hline LOSS & & & $\begin{array}{l}0.477^{*} \\
(0.254)\end{array}$ & $\begin{array}{l}0.457^{*} \\
(0.252)\end{array}$ & & & & & & \\
\hline Control Variables & & & & & & & & & & \\
\hline LEVER & $\begin{array}{l}-0.501 \\
(0.461)\end{array}$ & $\begin{array}{l}-0.455 \\
(0.458)\end{array}$ & $\begin{array}{l}-0.509 \\
(0.464)\end{array}$ & $\begin{array}{l}-0.400 \\
(0.458)\end{array}$ & $\begin{array}{l}-0.544 \\
(0.464)\end{array}$ & $\begin{array}{l}-0.507 \\
(0.461)\end{array}$ & $\begin{array}{l}-0.503 \\
(0.461)\end{array}$ & $\begin{array}{l}-0.451 \\
(0.458)\end{array}$ & $\begin{array}{l}-0.396 \\
(0.455)\end{array}$ & $\begin{array}{l}-0.505 \\
(0.460)\end{array}$ \\
\hline MTBV & $\begin{array}{c}0.00902 \\
(0.00932)\end{array}$ & $\begin{array}{c}0.00949 \\
(0.00923)\end{array}$ & $\begin{array}{c}0.00846 \\
(0.00895)\end{array}$ & $\begin{array}{c}0.00838 \\
(0.00889)\end{array}$ & $\begin{array}{c}0.00920 \\
(0.00930)\end{array}$ & $\begin{array}{c}0.00900 \\
(0.00934)\end{array}$ & $\begin{array}{c}0.00899 \\
(0.00932)\end{array}$ & $\begin{array}{c}0.00947 \\
(0.00941)\end{array}$ & $\begin{array}{c}0.00874 \\
(0.00939)\end{array}$ & $\begin{array}{c}0.00904 \\
(0.00931)\end{array}$ \\
\hline DUAL & $\begin{array}{l}0.0920 \\
(0.163)\end{array}$ & $\begin{array}{l}0.0777 \\
(0.162)\end{array}$ & $\begin{array}{l}0.0924 \\
(0.162)\end{array}$ & $\begin{array}{l}0.152 \\
(0.161)\end{array}$ & $\begin{array}{c}0.173 \\
(0.163)\end{array}$ & $\begin{array}{l}0.0872 \\
(0.163)\end{array}$ & $\begin{array}{l}0.0908 \\
(0.163)\end{array}$ & $\begin{array}{l}0.0762 \\
(0.156)\end{array}$ & $\begin{array}{l}0.0793 \\
(0.155)\end{array}$ & $\begin{array}{l}0.0980 \\
(0.162)\end{array}$ \\
\hline $\begin{array}{l}\text { Interaction variables } \\
\text { NED*REGQUA }\end{array}$ & & & & & & $\begin{array}{l}-0.000117 \\
(7.93 e-05)\end{array}$ & & & & \\
\hline NED*SIPI & & & & & & & $\begin{array}{l}-0.00170 \\
(0.00105)\end{array}$ & & & \\
\hline ECBI*GOVEFFEC & & & & & & & & $\begin{array}{l}0.00316 \\
(0.0137)\end{array}$ & & \\
\hline ECBI*RULEOFLAW & & & & & & & & & $\begin{array}{l}0.00253 \\
(0.0119)\end{array}$ & \\
\hline BCT*REGQUA & & & & & & & & & & $\begin{array}{r}0.00409 * * \\
(0.00183)\end{array}$ \\
\hline Constant & $\begin{array}{c}-4.390 * * \\
(1.783)\end{array}$ & $\begin{array}{c}-4.434 * * \\
(1.773)\end{array}$ & $\begin{array}{c}-4.971 * * * \\
(1.775)\end{array}$ & $\begin{array}{c}-4.191 * * \\
(1.776)\end{array}$ & $\begin{array}{l}-1.804 \\
(1.838)\end{array}$ & $\begin{array}{c}-5.094 * * * \\
(1.802)\end{array}$ & $\begin{array}{c}-5.174 * * * \\
(1.811)\end{array}$ & $\begin{array}{c}-3.700 * * \\
(1.806)\end{array}$ & $\begin{array}{c}-3.727 * * \\
(1.781)\end{array}$ & $\begin{array}{c}-4.288 * * \\
(1.792)\end{array}$ \\
\hline Observations & 377 & 377 & 377 & 377 & 377 & 377 & 377 & 377 & 377 & 377 \\
\hline Pseudo R2 & 0.1980 & 0.1817 & 0.1820 & 0.1731 & 0.2084 & 0.1970 & 0.1978 & 0.1903 & 0.1852 & 0.1965 \\
\hline
\end{tabular}

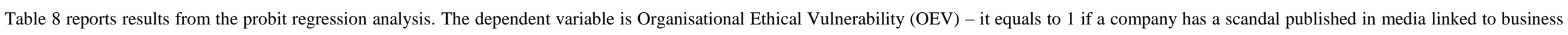

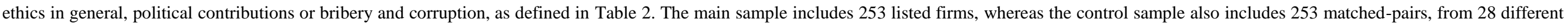

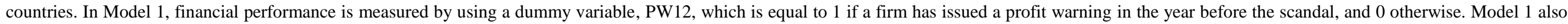

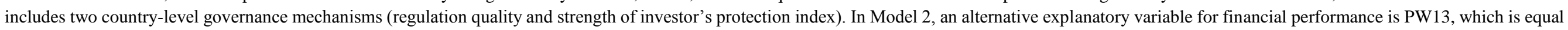

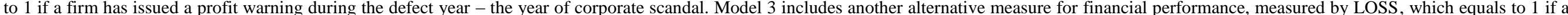

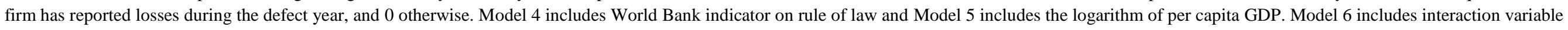

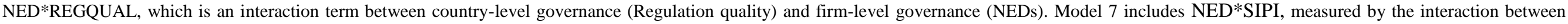

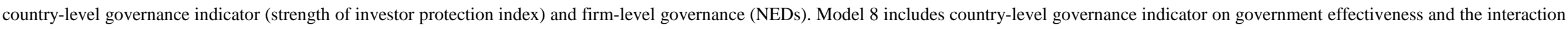

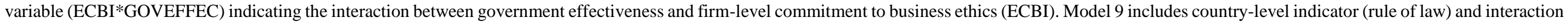

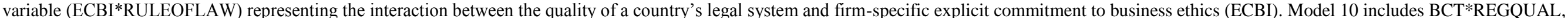
which represents the interaction between country-level regulation quality and the provision of firm-level bribery and corruption training programmes (BCT). 


\begin{tabular}{|c|c|c|}
\hline Variables & IV-Probit & Marginal effects \\
\hline BSIZE & $\begin{array}{l}0.226 * * * \\
(0.0417)\end{array}$ & 0.0194 \\
\hline NEDs & $\begin{array}{c}-0.0106 \\
(0.00835)\end{array}$ & -0.00321 \\
\hline NBM & $\begin{array}{c}0.0382 * * \\
(0.0167)\end{array}$ & $0.0131 * *$ \\
\hline GD & $\begin{array}{c}0.00631 \\
(0.00728)\end{array}$ & 0.00386 \\
\hline DUAL & $\begin{array}{c}0.137 \\
(0.154)\end{array}$ & 0.0301 \\
\hline SBO & $\begin{array}{c}-0.0127 * * * \\
(0.00454)\end{array}$ & -0.00315 \\
\hline LOGTSEC & $\begin{array}{c}0.323^{* * * *} \\
(0.08433)\end{array}$ & 0.245 \\
\hline ACI & $\begin{array}{c}-0.00510 \\
(0.0122)\end{array}$ & -0.000176 \\
\hline BCT & $\begin{array}{c}0.166 * * * \\
(0.0617)\end{array}$ & 0.137 \\
\hline ECBI & $\begin{array}{c}0.292 \\
(0.209)\end{array}$ & 0.0152 \\
\hline LEVER & $\begin{array}{l}-0.236 \\
(0.388)\end{array}$ & -0.152 \\
\hline PW12 & $\begin{array}{c}0.487 * * * \\
(0.152)\end{array}$ & 0.190 \\
\hline REGQUA & $\begin{array}{c}-0.0118^{* * * *} \\
(0.00528)\end{array}$ & -0.00803 \\
\hline SKILL & $\begin{array}{c}0.00313 \\
(0.00327)\end{array}$ & -0.000855 \\
\hline Constant & $\begin{array}{c}-3.386^{* *} \\
(1.384)\end{array}$ & \\
\hline Observations & 378 & \\
\hline
\end{tabular}

Marginal effects are calculated for Model 1 using the partial derivative of outcome probability with respect to the difference variable, evaluated at the other difference variable means. Marginal effects measure the percentage of likelihood to engage in unethical activities.

\section{Endnotes}

1 The laws governing corporate behaviour such as anti-bribing legislation might have ethical motivation.

2 https://en.oxforddictionaries.com/definition/scandal

3 Broadly, in corporate governance literature corporate reporting constitutes an important element that enhances transparency. We do not cover corporate reporting in this study; however, Chen and Roberts (2010) argue about the overlaps in these theories and discuss legitimacy and institutional theories in the corporate governance context, which is relevant to our search for factors that may explain organisational ethical vulnerability.

4 The application of panel data was not an appropriate option in this investigation because the scandals were not repetitive in subsequent years and appropriate matched firms were also not available. Thus, by using a strict matching criterion, control firms were chosen from the same industry, country and of similar size. 